\title{
De doorstroom van het reguliere naar het niet- reguliere onderwijs
}

Citation for published version (APA):

Matheeuwsen, A., \& de Grip, A. (1997). De doorstroom van het reguliere naar het niet-reguliere onderwijs. Researchcentrum voor Onderwijs en Arbeidsmarkt, Faculteit der Economische Wetenschappen. ROA Working Papers No. 4 https://doi.org/10.26481/umarow.1997004

Document status and date:

Published: 01/01/1997

DOI:

10.26481/umarow.1997004

Document Version:

Publisher's PDF, also known as Version of record

\section{Please check the document version of this publication:}

- A submitted manuscript is the version of the article upon submission and before peer-review. There can be important differences between the submitted version and the official published version of record.

People interested in the research are advised to contact the author for the final version of the publication, or visit the DOI to the publisher's website.

- The final author version and the galley proof are versions of the publication after peer review.

- The final published version features the final layout of the paper including the volume, issue and page numbers.

Link to publication

\footnotetext{
General rights rights.

- You may freely distribute the URL identifying the publication in the public portal. please follow below link for the End User Agreement:

www.umlib.nl/taverne-license

Take down policy

If you believe that this document breaches copyright please contact us at:

repository@maastrichtuniversity.nl

providing details and we will investigate your claim.
}

Copyright and moral rights for the publications made accessible in the public portal are retained by the authors and/or other copyright owners and it is a condition of accessing publications that users recognise and abide by the legal requirements associated with these

- Users may download and print one copy of any publication from the public portal for the purpose of private study or research.

- You may not further distribute the material or use it for any profit-making activity or commercial gain

If the publication is distributed under the terms of Article $25 \mathrm{fa}$ of the Dutch Copyright Act, indicated by the "Taverne" license above, 
De doorstroom van het reguliere naar het niet-reguliere onderwijs

ROA-W-1997/4

Astrid Matheeuwsen en Andries de Grip

Researchcentrum voor Onderwijs en Arbeidsmarkt

Faculteit der Economische Wetenschappen en Bedrijfskunde Universiteit Maastricht

Maastricht, juni 1997 
ISBN 90-5321-207-8

SEC97.082

Inhoud 
Bladzijde

Voorwoord

1 Inleiding 1

2 Huidige methodiek instroomprognoses 3

2.1 Inleiding 3

2.2 Methodiek instroom van schoolverlaters op de arbeidsmarkt 3

$\begin{array}{ll}2.3 \text { Actuele en toekomstige instroomontwikkelingen } & 6\end{array}$

3 Onderwijsrekeningen $\quad 13$

3.1 Inleiding 13

3.2 Opbouw om te komen tot vergelijkbare gegevens 13

3.3 Niet-regulier onderwijs naar onderwijsniveau, -richting en vooropleiding 17

4 Vergelijking huidige instroomgegevens met Onderwijsrekeningen 28

5 Samenvatting en conclusie $\quad 34$

$\begin{array}{ll}\text { Literatuur } & 36\end{array}$ 


\section{Voorwoord}

Elk jaar worden in het kader van het Informatiesysteem Onderwijs-Arbeidsmarkt van het Researchcentrum voor Onderwijs en Arbeidsmarkt middellange-termijn prognoses opgesteld voor de toekomstige instroom van schoolverlaters naar de arbeidsmarkt. Bij de bepaling van deze instroomprognoses worden naast de arbeidsmarktinstroom vanuit het reguliere voltijdonderwijs ook de niveauverhogende of opleidingsrichting-veranderende scholingsactiviteiten in het niet-reguliere onderwijs meegenomen. De gegevens die tot op heden over deze laatste opleidingen werden verzameld zijn vaak gebrekkig, in de zin dat zowel de betrouwbaarheid van de beschikbare data als de gedetailleerdheid van de gegevens tekort schiet. Bovendien zijn de gegevens afkomstig uit vele verschillende onderling niet goed vergelijkbare bronnen.

In dit werkdocument worden op basis van de Onderwijsrekeningen 1995/'96 van het Centraal Bureau voor de Statistiek gegevens gegenereerd die de kwalificatieverouderde rol van het niet-reguliere onderwijs op meer consistente wijze in beeld brengen. Op basis van een vergelijking tussen de gegevens die zijn gebruikt voor de meest recente arbeidsmarktinstroomprognoses in de periode 1995-2000 en de gegevens die resulteren uit de Onderwijsrekeningen is onderzocht in hoeverre de Onderwijsrekeningen mogelijkheden bieden om de kwaliteit van de prognoses van de arbeidsmarktinstroom vanuit deze ('niet-reguliere') opleidingen te verbeteren.

De auteurs danken drs. Fred Gast, drs. Roel Schaart en drs. Jan Willem Altena van het Centraal Bureau voor de Statistiek voor hun begeleiding bij het genereren en interpreteren van de gegevens uit de Onderwijsrekeningen. 


\section{Inleiding}

Vanuit het Informatiesysteem Onderwijs-Arbeidsmarkt van het Researchcentrum voor Onderwijs en Arbeidsmarkt (ROA) worden elke twee jaar middellange-termijn arbeidsmarktprognoses naar beroepsklasse en opleidingstype opgesteld. De meest recente prognoses hebben betrekking op de periode 1995-2000 (ROA, 1995 en 1996). Om vraag en aanbod op de arbeidsmarkt adequaat met elkaar te kunnen confronteren is het cruciaal dat aan de aanbodkant naast de arbeidsmarktinstroom vanuit het reguliere voltijdonderwijs (stap 1 van de instroomprognose) ${ }^{1}$ ook andere niveauverhogende of opleidingsrichtingveranderende scholingsactiviteiten van de beroepsbevolking in kaart worden gebracht (stap 2 van de instroomprognose) $)^{2}$.

Deze tweede stap van de arbeidsmarktinstroomprognose heeft in feite betrekking op het reguliere deeltijdonderwijs en het niet-reguliere onderwijs ${ }^{3}$. Bij de gegevens die voor stap 2 worden verzameld, doet zich echter een tweetal problemen voor. Ten eerste is de betrouwbaarheid en gedetailleerdheid van de gegevens doorgaans aanzienlijk lager dan bij de informatie over het reguliere voltijdonderwijs. Het tweede probleem is dat er, door het ontbreken van adequate informatie over de vooropleiding, vaak een vrij arbitraire beslissing over het eventueel niveauverhogende of opleidingsrichting-veranderende karakter van de niet-reguliere opleiding genomen moet worden.

Tot nu toe werd in stap 2 de doorstroom naar het deeltijdonderwijs en het niet-reguliere onderwijs bepaald op basis van gegevens uit vele verschillende bronnen (bijvoorbeeld Onderwijsstatistieken van het Centraal Bureau voor de Statistiek (CBS), gegevens van de Vereniging van Samenwerkende Nederlandse Universiteiten (VSNU) en gegevens van het Landelijk Selectiecentrum voor de politie). In deze tweede stap gaat het, zoals gezegd, om het bepalen van het aantal personen dat een niet-reguliere opleiding met een diploma afsluit én waarvoor de gevolgde opleiding op een hoger niveau dan de gevolgde vooropleiding ligt of betrekking heeft op een andere opleidingsrichting. Bij diverse niet-reguliere opleidingen is zowel het aantal gediplomeerden als de vooropleiding niet bekend. In dat geval wordt op basis van bijvoorbeeld het aantal cursisten in een bepaald jaar en de nominale studieduur een schatting gemaakt van het aantal gediplomeerden, terwijl er bovendien veronderstellingen worden gemaakt over het percentage gediplomeerden waarbij er sprake is van een niveauverhogende of opleidingsrichting-veranderende oplei-

1. De prognose van de arbeidsmarktinstroom vanuit het reguliere voltijdonderwijs is gebaseerd op de Referentieraming. Met deze prognose ligt de totale instroom van nieuwkomers op de arbeidsmarkt vast.

2. In stap 2 wordt de arbeidsmarktinstroom bijgesteld door rekening te houden met de doorstroom naar het 'niet-reguliere' onderwijs. Een dergelijke verschuiving van de opleidingsachtergrond van het arbeidsaanbod vindt plaats als iemand een 'niet-reguliere' opleiding voltooit die op een hoger niveau ligt of betrekking heeft op een andere opleidingsrichting dan de opleiding die men eerder in het reguliere voltijdonderwijs heeft behaald.

3. In het vervolg van dit werkdocument zal het reguliere deeltijdonderwijs en het niet-reguliere deel van het onderwijs tezamen het niet-reguliere onderwijs worden genoemd. 
ding. Hierbij wordt bijvoorbeeld rekening gehouden met de leeftijd van de cursisten en de vooropleidingen van vergelijkbare reguliere voltijdopleidingen. Er wordt in een aantal gevallen verondersteld dat het kwalificatieprofiel van personen die een niet-reguliere opleiding hebben gevolgd en ouder zijn dan 30 jaar niet verandert. Ook opleidingen met een duur van minder dan 6 maanden worden niet meegenomen omdat deze naar alle waarschijnlijkheid niet substantieel genoeg zijn om te spreken van een niveauverhogende of richtingveranderende opleiding. Dit laatste benadert ook de consistentie met de vraagprognoses. De aan de vraagprognoses ten grondslag liggende Enquête Beroepsbevolking (EBB) hanteert immers hetzelfde criterium voor de bepaling van de hoogst behaalde opleiding.

Sinds een aantal jaren werkt het CBS in het kader van de integratie van haar gegevens aan de Onderwijsrekeningen. In de Onderwijsrekeningen worden onder andere de data van de Enquête Beroepsbevolking en de Onderwijsstatistieken van het CBS gecombineerd. Omdat de ROA-prognoses voor de vraagzijde van de arbeidsmarkt ook op EBBinformatie berusten kan een vergelijking van de gegevens uit de Onderwijsrekeningen met de gegevens die tot nu toe worden gebruikt bij het bepalen van de arbeidsmarktinstroom vanuit het niet-reguliere onderwijs aangeven:

- welke doorstroom naar het niet-reguliere onderwijs wordt onderschat of overschat;

- in hoeverre deze stromen door hun niveauverhogend of opleidingsrichting-veranderende karakter relevant zijn voor de confrontatie van vraag en aanbod op de arbeidsmarkt.

Hierdoor kan een beter beeld ontstaan van de betekenis van scholingsactiviteiten buiten het reguliere (initiële) voltijdonderwijs voor het opleidingsprofiel van het arbeidsaanbod in de prognoseperiode. Dit is temeer van belang daar de omvang van deze scholingsactiviteiten sinds het midden van de jaren tachtig duidelijk toeneemt (zie De Grip cs., 1997).

Onderzocht zal worden in hoeverre de Onderwijsrekeningen mogelijkheden bieden om de kwaliteit van de prognoses van de arbeidsmarktinstroom vanuit het niet-reguliere onderwijs te verbeteren. Om hier een beeld van te kunnen krijgen, zullen de huidige prognoses voor het niet-reguliere onderwijs vergeleken worden met de gegevens uit de Onderwijsrekeningen.

Een voordeel van de gegevens uit de Onderwijsrekeningen is ook dat de cijfers betrekking hebben op een schooljaar van september tot juni, waardoor de cijfers goed aansluiten bij de in de eerste stap gegenereerde stroomcijfers uit het reguliere voltijdonderwijs.

Voor de analyses is gebruik gemaakt van de Onderwijsrekeningen voor het schooljaar 1995/'96. Het betreft voorlopige gegevens. De cijfers zijn voorlopig omdat op het moment van onderzoek nog niet alle informatie beschikbaar was (september-maart). Het nadeel hiervan is dat er minder waarnemingen zijn. Een belangrijk voordeel van de Onderwijsrekeningen 1995/'96 is echter dat hierin voor het eerst het identificatienummer is opgenomen. Op basis van dit identificatienummer kan op MBO-niveau onderscheid worden gemaakt tussen MBO- en leerlingwezenopleidingen. 
De verdere opzet van dit werkdocument is als volgt. Eerst wordt in hoofdstuk 2 een korte beschrijving gegeven van de huidige methodiek van de arbeidsmarktinstroomprognoses en de daarbij noodzakelijkerwijs te maken veronderstellingen. Vervolgens zal op basis van de meest recente instroomprognoses voor de periode 1995-2000 een beeld worden gegeven van de opbouw van deze prognoses, qua omvang van de verschillende stromen. Daarbij wordt de verhouding weergegeven tussen het aantal schoolverlaters vanuit het reguliere voltijdonderwijs en het aantal personen dat door een niet-reguliere opleiding van opleidingsachtergrond is veranderd. Eveneens wordt per onderwijsniveau gekeken naar de vooropleidingen en de opleidingsrichtingen van de arbeidsmarktinstroom van schoolverlaters uit het niet-reguliere onderwijs. Vervolgens wordt in hoofdstuk 3 ingegaan op de analyse van het niet-reguliere onderwijs op basis van de Onderwijsrekeningen 1995/'96. Daarbij wordt ingegaan op de methoden die gehanteerd zijn om in de Onderwijsrekeningen het reguliere voltijdonderwijs van het niet-reguliere onderwijs af te bakenen en het niveauverhogende en richtingveranderende karakter van de niet-reguliere opleidingen te bepalen. Evenals in hoofdstuk 2 wordt per onderwijsniveau een beeld geschetst van de opleidingsrichtingen van de arbeidsmarktinstroom van het niet-reguliere onderwijs en de spreiding van de vooropleidingen. In hoofdstuk 4 worden de stroomgegevens die gegenereerd kunnen worden uit de Onderwijsrekeningen vergeleken met de doorstroomgegevens die bij de laatste prognoses gehanteerd zijn voor het bepalen van stap 2 van de arbeidsmarktinstroomprognoses. Ten slotte worden in hoofdstuk 5 de bevindingen uit deze vergelijking samengevat en wordt aangegeven wat de conclusies zijn met betrekking tot de toekomstige bepaling van de arbeidsmarktinstroomprognoses.

\section{Huidige methodiek instroomprognoses}

\subsection{Inleiding}

In dit hoofdstuk wordt kort ingegaan op de huidige methodiek van de prognoses van de instroom van nieuwkomers op de arbeidsmarkt. Eerst wordt in paragraaf 2.2 kort ingegaan op de huidige aanpak van de prognoses van de toekomstige arbeidsmarktinstroom vanuit het onderwijs. Daarna wordt in paragraaf 2.3 nader ingegaan op de noodzakelijkerwijs te maken veronderstellingen met betrekking tot de arbeidsmarktinstroom vanuit het nietreguliere onderwijs. In aansluiting daarop wordt in deze paragraaf een beeld geschetst van de, op basis van de huidige methodiek met betrekking tot de arbeidsmarktinstroom vanuit het niet-reguliere onderwijs vastgestelde omvang van de opleidingsniveau-verhogende of opleidingsrichting-veranderende arbeidsmarktinstroom vanuit het niet-reguliere onderwijs.

\subsection{Methodiek instroom van schoolverlaters op de arbeidsmarkt}

Figuur 2.1 geeft een schematisch overzicht van de opbouw van de instroomprognose. In het prognosemodel worden twee stappen onderscheiden. In de eerste stap wordt de prognose opgesteld van de verwachte toekomstige uitstroom uit het reguliere voltijdonderwijs. Uitgangspunt bij de prognoses voor de periode 1995-2000 was de Referentieraming 
1995 van het Ministerie van Onderwijs, Cultuur en Wetenschappen (1995). Met deze prognose ligt de totale instroom van nieuwkomers op de arbeidsmarkt vanuit het onderwijs vast.

Voor veel schoolverlaters betekent het verlaten van het reguliere voltijdonderwijs echter niet dat de schoolloopbaan is beëindigd. Degenen die het voltijdonderwijs verlaten kunnen binnen de prognoseperiode nog doorstromen naar het deeltijdonderwijs, het niet-reguliere voltijdonderwijs en het beroepsgerichte volwassenenonderwijs. Als men daar een diploma behaald én de gevolgde opleiding heeft een hoger niveau dan de genoten vooropleiding of verandert de opleidingsrichting van de betrokkenen, dan moet de instroomprognose worden aangepast. Deze bijstelling vindt plaats in stap twee. Daarbij vermindert het potentiële arbeidsaanbod bij de opleidingscategorie waartoe de vooropleiding wordt gerekend en neemt het aanbod toe bij het opleidingstype waartoe de gevolgde opleiding behoort. Globaal gesproken kunnen in het prognosemodel derhalve twee stappen worden onderscheiden.

\section{Stap 1}

Uit de Referentieraming resulteert het verwachte aantal schoolverlaters per schoolsoort voor de prognoseperiode. Hierbij is een onderscheid gemaakt tussen de schoolverlaters met diploma en de schoolverlaters zonder diploma. Degenen die het reguliere voltijdonderwijs zonder diploma verlaten kunnen echter reeds eerder een opleiding met diploma hebben afgesloten. De ongediplomeerde schoolverlaters worden dan ook toegewezen aan de hoogst voltooide voltijd-vooropleiding. Deze hoogst voltooide voltijdopleiding is bepaald met behulp van de Onderwijsmatrix 1992 van het CBS (1992). Op deze wijze resulteert het verwachte toekomstige aantal schoolverlaters met diploma per schoolsoort en -richting. Hierna vindt een verbijzondering plaats om deze toekomstige uitstroom uit het reguliere voltijdonderwijs naar de arbeidsmarkt voor de 79 onderscheiden opleidingstypen te bepalen. Deze verdeling vindt plaats met behulp van verdeelsleutels die zijn berekend op basis van feitelijke gegevens over het aantal gediplomeerden van elk opleidingstype binnen een schoolsoort (zie Borghans en Matheeuwsen, 1997).

$\mathrm{Na}$ deze versleuteling resulteert het totaal aantal verwachte toekomstige schoolverlaters en vindt er alleen nog een herverdeling plaats vanwege de veranderingen in het opleidingsniveau of de opleidingsrichting van de schoolverlaters na het verlaten van het reguliere voltijdonderwijs.

\section{Stap 2}

In stap 2 wordt, zoals reeds is aangegeven, de instroomprognose aangepast door rekening te houden met de doorstroom naar het deeltijdonderwijs, niet-reguliere voltijdonderwijs of beroepsgerichte volwasseneneducatie. Als iemand een dergelijke opleiding met een diploma afsluit én de gevolgde opleiding ligt op een hoger niveau of heeft betrekking op 
Figuur 2.1

Globaal schema ter bepaling van de verwachte toekomstige instroom van schoolverlaters op de arbeidsmarkt naar ROA-opleidingstype

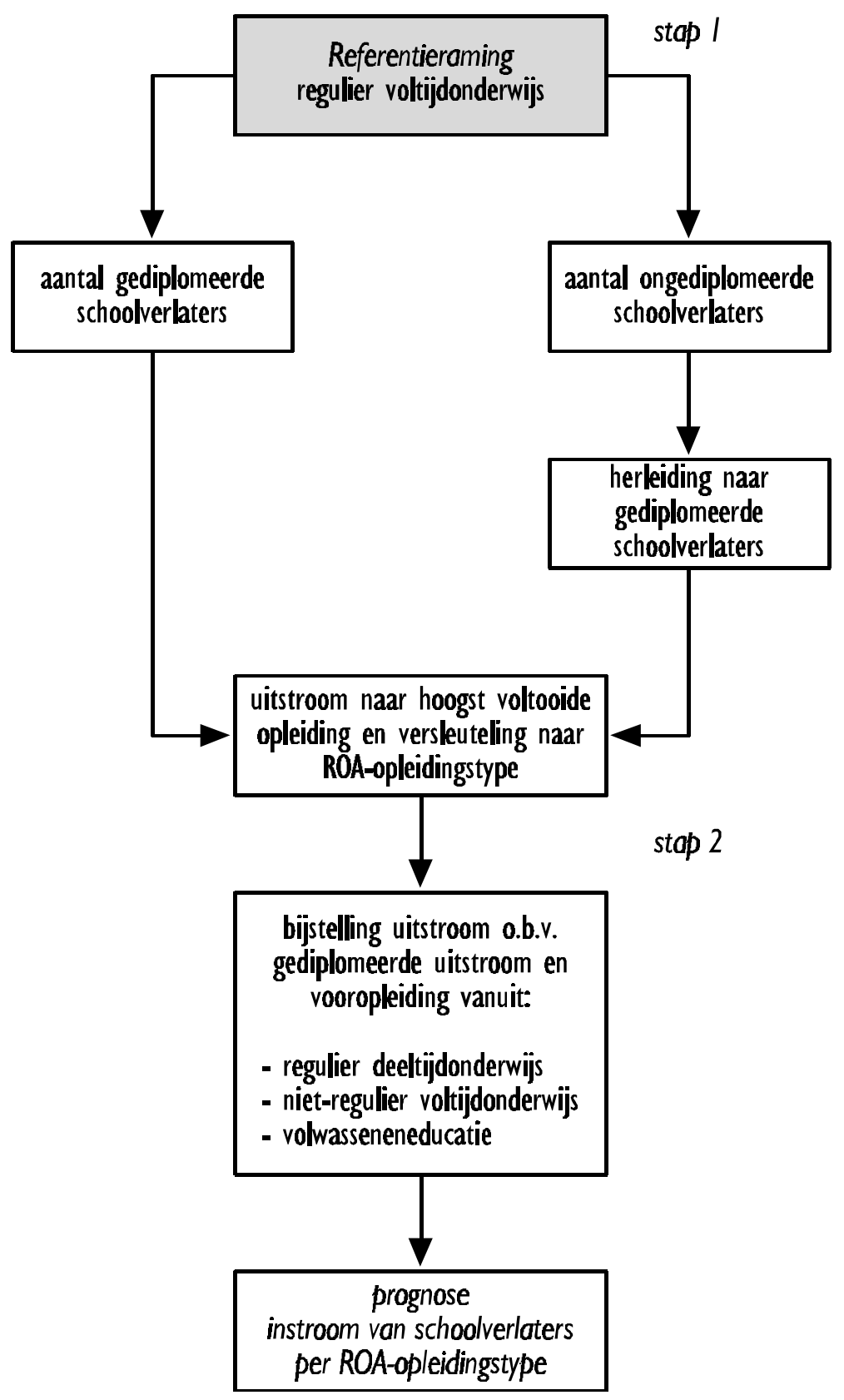

andere opleidingsrichting dan de gevolgde vooropleiding, dan vermindert de arbeidsmarktinstroom uit stap 1 bij het opleidingstype waartoe de vooropleiding behoort, terwijl de ar- 
beidsmarktinstroom waartoe de reguliere deeltijd-, niet-reguliere voltijd- of beroepsgerichte volwassenenopleiding wordt gerekend, toeneemt.

Deze herverdeling van de uitstroom uit het reguliere voltijdonderwijs vereist niet alleen data over het aantal gediplomeerden dat uitstroomt uit de reguliere deeltijd-, de niet-reguliere en de volwassenenopleidingen naar de arbeidsmarkt, maar ook informatie over de vooropleiding van deze gediplomeerden. In de tweede stap is onder meer gebruik gemaakt van gegevens van de VSNU, het CBS (o.a. Onderwijsstatistieken), het Ministerie van Onderwijs, Cultuur en Wetenschappen (o.a. de Opgave van Leerlingwezen (OVL)) en het Landelijk Selectiecentrum voor de politie. Voorbeelden van regulier deeltijdonderwijs en nietregulier onderwijs zijn: de deeltijdopleidingen $\mathrm{MBO}$ en $\mathrm{HBO}$, de volwasseneneducatie, Open Universiteit, gezondheidszorgopleidingen, scholingsmaatregelen van de Arbeidsvoorzieningsorganisatie, bedrijfsopleidingen, het Buitenschools Mondeling Onderwijs (BMO), het Erkend Schriftelijk Onderwijs (ESO), Cursorisch Ondernemers Onderwijs (COO), bestuursdienstonderwijs, de politieopleidingen, brandweeropleidingen en defensie-opleidingen.

$\mathrm{Na}$ de bijstelling in stap 2 van de uitstroom uit het reguliere voltijdonderwijs resulteert de toekomstige instroom van schoolverlaters op de arbeidsmarkt voor de 79 onderscheiden opleidingstypen voor de prognoseperiode 1995-2000.

\subsection{Actuele en toekomstige instroomontwikkelingen}

Zoals reeds eerder is aangegeven, zijn de gegevens die tot op heden worden gebruikt om de uitstroom uit het niet-regulier onderwijs te bepalen afkomstig uit een aantal verschillende bronnen. Voor de arbeidsmarktinstroomprognoses is alleen dat deel van de uitstroom van het niet-reguliere onderwijs van belang dat:

- de opleiding (in een bepaald jaar) met een diploma afsluit;

- door het behalen van de opleiding van kwalificatieprofiel qua opleidingstype (d.w.z. opleidingsniveau of -richting) verandert.

Idealiter zouden dus van de gevolgde niet-reguliere opleiding gegevens beschikbaar moeten zijn over:

- het opleidingstype waartoe de opleiding gerekend kan worden;

- het behalen van het diploma;

- de vooropleiding;

- of er sprake is van een verandering van het kwalificatieprofiel.

Bij veel opleidingen zijn de meeste van deze gegevens echter onbekend.

\section{Opleidingstype}

Van een aantal niet-reguliere opleidingen is de richting van de opleiding alleen op een te hoog aggregratieniveau bekend, zodat van deze opleidingen niet kan worden bepaald tot welk opleidingstype ze behoren. Het gaat om de prognoses van de gediplomeerde school- 
verlaters van de deeltijdopleidingen op VBO, MBO en HBO-niveau, het leerlingwezen (LLW) en de inservice-opleidingen. De verdeling van deze gegevens naar opleidingsrichting vindt plaats met behulp van verdeelsleutels. Deze verdeelsleutels zijn berekend op basis van feitelijke gegevens over het aantal studenten danwel gediplomeerden van elke opleidingsrichting binnen deze opleidingen. Een voorbeeld: de Referentieraming geeft een prognose van het totaal aantal gediplomeerde schoolverlaters van de deeltijdopleidingen op MBO-niveau. Met behulp van actuele gegevens van het CBS over de verdeling van het aantal gediplomeerden van het MBO-deeltijdonderwijs naar opleidingsrichting wordt de prognose van het totaal aantal gediplomeerde schoolverlaters van de deeltijdopleidingen op MBO-niveau verbijzonderd naar de in het deeltijdonderwijs voorkomende MBO-opleidingsrichtingen (bijvoorbeeld landbouw en natuurlijke omgeving, bouwkunde, handel en verzorging).

\section{Gediplomeerden}

Bij verschillende niet-reguliere opleidingen is slechts het totaal aantal cursisten of het aantal instromers (eerste-jaars) in een bepaald jaar bekend. Er moeten dan veronderstellingen worden gemaakt over het percentage cursisten dat de opleiding met goed gevolg voltooit (het slaagpercentage). Deze veronderstellingen zijn meestal gebaseerd op verhoudingsgetallen e.d. zoals ze bij verwante opleidingen in het reguliere onderwijs worden aangetroffen. Voorbeelden van niet-reguliere opleidingen waarvan het aantal geslaagden onbekend is, zijn: WO- $2^{\mathrm{e}}$ fase lerarenopleidingen, de gevangenisbewaarders- en politieopleidingen, inservice-opleidingen, NIVRA-opleidingen, Open Universiteit, landbouwvakscholen, bestuursdienstonderwijs, ESO/BMO en het Rijksopleidingeninstituut.

Voor veel niet-reguliere opleidingen waarvoor gegevens beschikbaar zijn van het CBS, is het aantal gediplomeerden wel bekend. Voorbeelden hiervan zijn de theologische opleidingen, het cursorisch ondernemersonderwijs en de $2^{\mathrm{e}}$ fase HBO-opleidingen. Voor sommige opleidingen die in stap 2 moeten worden meegenomen, geeft de Referentieraming zelfs prognoses van het aantal gediplomeerde schoolverlaters. Het betreft hier gegevens van de reguliere deeltijdopleidingen MAVO, HAVO, VBO, MBO en HBO. Voor deze opleidingen hoeven derhalve geen veronderstellingen over het diploma-bezit gemaakt te worden.

\section{Vooropleiding en verandering kwalificatieprofiel}

Van de meeste niet-reguliere opleidingen is de vooropleiding van de studenten onbekend, of kan deze slechts worden gebaseerd op gegevens van een aantal jaren terug. In een aantal gevallen kan gebruik worden gemaakt van gegevens op een hoger aggregratieniveau (bijvoorbeeld vooropleiding op HBO-niveau, waarbij er geen informatie bekend is over de opleidingsrichting). Er moeten dan veronderstellingen worden gemaakt over de spreiding van de vooropleidingen op het desbetreffende opleidingsniveau. Evenals bij de veronderstellingen die moeten worden gemaakt over het slaagpercentage, zijn de veronderstellingen die worden gemaakt over de vooropleiding meestal gebaseerd op verhoudingsgetallen e.d. zoals ze bijvoorbeeld bij verwante opleidingen in het reguliere onderwijs 
worden aangetroffen. Dergelijke aannames kunnen vanzelfsprekend leiden tot vertekeningen, met name ook omdat waarschijnlijk veel niet-reguliere opleidingen in dezelfde richting liggen als de gevolgde initiële opleiding, of onvoldoende substantieel zijn om daadwerkelijk te spreken van een verandering van het kwalificatieprofiel (bijvoorbeeld een talencursus voor technisch opgeleiden). Daarom wordt in het algemeen een zeer conservatieve schatting gemaakt van de veranderingen die optreden in het kwalificatieprofiel. Dit betekent dat voor een aantal niet-reguliere opleidingen wordt verondersteld dat slechts bij een gering deel van de geslaagden het kwalificatieprofiel verandert. Voorbeelden zijn cursussen in het kader van het Erkend Schriftelijk Onderwijs of Buitenschools Mondeling Onderwijs (ESO/BMO), het Rijksopleidingeninstituut en het bestuursdienstonderwijs waarvan voor slechts $10 \%$ van de gediplomeerden wordt verondersteld dat het kwalificatieprofiel verandert. Bij een aantal niet-reguliere opleidingen (bijvoorbeeld de deeltijdopleidingen op VBO, MBO en HBO-niveau) wordt bij het bepalen van de mate waarin er sprake is van een verandering van het kwalificatieprofiel, ook gebruik gemaakt van de leeftijdsverdeling van de studenten. Er wordt verondersteld dat voor personen boven de 30 jaar de nietreguliere opleidingen het kwalificatieprofiel van de betrokkenen niet meer verandert maar alleen een verbreding of verdieping geeft van de kennis en vaardigheden waarover men reeds beschikt.

De gegevens over defensie-opleidingen, de scholingsmaatregelen van de Arbeidsvoorzieningsorganisatie en een deel van de bewakings- en politie-opleidingen zijn kwalitatief het minst. Voor deze niet-reguliere opleidingen moet worden uitgegaan van gegevens die op een erg hoog aggregatieniveau liggen en bovendien slechts gebaseerd zijn op schattingen van sleutelpersonen.

Op basis van de gegevens die beschikbaar zijn over het niet-reguliere onderwijs en de daarbij gemaakte veronderstellingen resulteert het aantal personen dat een niveauverhogende danwel opleidingsrichting-veranderende niet-reguliere opleiding heeft gevolgd en hun vooropleiding. Dit resultaat wordt gebruikt om de in de eerste stap bepaalde uitstroom uit het reguliere voltijdonderwijs naar opleidingstype bij te stellen.

Tabel 2.1

Instroom van schoolverlaters uit het reguliere voltijd- en niet-reguliere onderwijs, 1990-1995, 1995-2000 en 1994

\begin{tabular}{|c|c|c|c|c|}
\hline & $\begin{array}{l}\text { Aantal \% } \\
1990-1995\end{array}$ & $\begin{array}{c}\text { Aantal \% } \\
1995-2000\end{array}$ & Aantal & $\begin{array}{r}\% \\
1994\end{array}$ \\
\hline Regulier voltijdonderwijs & $1.081 .500 \quad 100$ & 1.060 .200100 & 206.200 & 100 \\
\hline Niet-regulier onderwijs & 340.500 & $317.600 \quad 30$ & 65.400 & 32 \\
\hline
\end{tabular}

Bron: ROA (op basis van diverse databronnen, zie paragraaf 2.2)

Tabel 2.1 geeft een beeld van de verhouding tussen het aantal schoolverlaters uit het 
reguliere voltijdonderwijs (stap 1) en de (bijgestelde) arbeidsmarktinstroom vanuit het nietreguliere onderwijs (stap 2) in 1994 en in de perioden 1990-1995 en 1995-2000.

In de periode 1995-2000 zal naar verwachting, evenals in de periode 1990-1995, ongeveer 30 procent van de arbeidsmarktinstoom vanuit het reguliere voltijdonderwijs na hun reguliere voltijdopleiding nog een niveauverhogende of opleidingsrichting-veranderende nietreguliere opleiding volgen ${ }^{4}$. In 1994 zijn dit in totaal ruim 65.000 personen, de arbeidsmarktinstroom van schoolverlaters uit het reguliere voltijdonderwijs betreft in dit jaar in totaal ruim 206.000 personen.

In het vervolg van dit werkdocument zullen de onderscheiden opleidingsniveau's worden aangeduid met een bij het opleidingsniveau behorend nummer of een verkorte naam. Tabel 2.2 geeft een overzicht van de onderscheiden opleidingsniveau's met het bijbehorende opleidingsniveau-nummer van de Standaard Onderwijsindeling van het CBS en de verkorte naam.

Uit de tabel blijkt dat bijvoorbeeld opleidingsniveau 4 gelijk is aan MBO/LLW, HAVO/VWOniveau. In het vervolg zal vaak de verkorte naam worden gebruikt: MBO/LLW-niveau.

Tabel 2.2

Overzicht van de onderscheiden opleidingsniveau's met bijbehorend SOI-opleidingsniveau-nummer en verkorte naam

\begin{tabular}{lll}
\hline Opleidingsniveau & Opleidingsniveau & Verkorte naam \\
\hline & & \\
2 & Basisonderwijs & Basisonderwijs \\
3 & VBO, MAVO & VBO \\
4 & MBO/LLW, HAVO/VWO & MBO/LLW \\
5 & HBO & HBO \\
6 & WO & WO \\
7 & Post-WO & Post-WO \\
9 & Overig onderwijs & Overig onderwijs \\
\hline
\end{tabular}

In tabel 2.3 wordt de niveauverhogende of richtingveranderende arbeidsmarktinstroom van schoolverlaters uit het niet-reguliere onderwijs weergegeven naar onderwijsniveau en vooropleiding voor de perioden 1990-1995, 1995-2000 en het jaar 1994. De toekomstige arbeidsmarktinstroom van schoolverlaters uit het niet-reguliere onderwijs neemt ten opzichte van de periode $1990-1995$ met ongeveer $7 \%$ af van 340.500 tot 317.600 personen. Deze daling doet zich voor op MBO/LLW-, HBO- en WO-niveau. Daarentegen neemt de

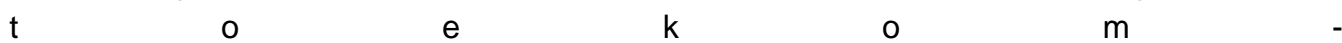

Tabel 2.3

Niveauverhogende of richtingveranderende arbeidsmarktinstroom van schoolverlaters uit het niet-reguliere

4. Strikt genomen hoeft het daarbij niet noodzakelijkerwijs om dezelfde personen te gaan, maar gaat het om het netto-effect. 
onderwijs naar onderwijsniveau en vooropleiding, 1990-1995, 1995-2000 en 1994

\begin{tabular}{|c|c|c|c|c|c|c|}
\hline \multirow[t]{2}{*}{ Vooropleiding } & \multicolumn{6}{|c|}{ Opleidingsniveau } \\
\hline & 3 & 4 & 5 & 6 & 7 & Totaal \\
\hline \multicolumn{7}{|l|}{ 1990-1995 } \\
\hline 2 Basisonderwijs & 28.000 & 48.900 & 0 & - & - & 76.900 \\
\hline 3 VBO, MAVO & 3.400 & 139.200 & 1.100 & 100 & - & 143.900 \\
\hline $4 \mathrm{MBO} / \mathrm{LLW}, \mathrm{HAVO} / \mathrm{VWO}$ & $2.000^{*}$ & 73.300 & 25.600 & 1.800 & - & 102.700 \\
\hline $5 \mathrm{HBO}$ & - & - & 3.000 & 7.700 & - & 10.700 \\
\hline 6 Wo & - & - & $100^{* *}$ & 0 & 1.800 & 1.900 \\
\hline 9 Overig onderwijs & - & 4.500 & - & - & - & 4.500 \\
\hline Totaal & 33.400 & 265.900 & 29.800 & 9.600 & 1.800 & 340.500 \\
\hline \multicolumn{7}{|l|}{$1995-2000$} \\
\hline 2 Basisonderwijs & 29.500 & 43.300 & 0 & - & - & 72.800 \\
\hline 3 VBO, MAVO & 3.000 & 132.300 & 1.000 & 100 & - & 136.400 \\
\hline $4 \mathrm{MBO} / \mathrm{LLW}, \mathrm{HAVO} / \mathrm{VWO}$ & $1.800^{*}$ & 64.600 & 24.000 & 1.000 & - & 91.300 \\
\hline $5 \mathrm{HBO}$ & - & - & 3.000 & 7.600 & - & 10.500 \\
\hline $6 \mathrm{WO}$ & - & - & $100^{* *}$ & 0 & 3.100 & 3.200 \\
\hline 9 Overig onderwijs & - & 3.400 & - & - & - & 3.400 \\
\hline Totaal & 34.300 & 243.600 & 28.000 & 8.700 & 3.100 & 317.600 \\
\hline \multicolumn{7}{|l|}{1994} \\
\hline 2 Basisonderwijs & 5.700 & 9.200 & 0 & - & - & 14.900 \\
\hline 3 VBO, MAVO & 600 & 27.200 & 200 & 0 & - & 28.100 \\
\hline $4 \mathrm{MBO} / \mathrm{LLW}, \mathrm{HAVO} / \mathrm{VWO}$ & $400^{*}$ & 13.400 & 5.100 & 200 & - & 19.100 \\
\hline $5 \mathrm{HBO}$ & - & - & 600 & 1.500 & - & 2.100 \\
\hline 6 WO & - & - & $0^{\star *}$ & 0 & 400 & 400 \\
\hline 9 Overig onderwijs & - & 700 & - & - & - & 700 \\
\hline Totaal & 6.700 & 50.500 & 5.900 & 1.800 & 400 & 65.400 \\
\hline
\end{tabular}

Bron: ROA (op basis van diverse databronnen, zie paragraaf 2.2)

* Enkele niet-reguliere opleidingen op opleidingsniveau 3 blijken leerlingen met een vooropleiding op niveau 4 te hebben. Het gaat hier om een aantal LLW-opleidingen die op opleidingsniveau 3 zijn geclassificeerd. Omdat alleen van alle LLW-opleidingen tezamen de verdeling over de vooroplei-dingen bekend is, kan bij de toerekening van de instroom in het leerlingwezen aan de gevolgde vooropleidingen, de instroom van een LLW-opleiding met opleidingsniveau 3 worden toegerekend aan een vooropleiding op niveau 4.

** Er blijkt dat een klein aantal opleidingen met opleidingsniveau 5 afgestudeerden heeft met vooropleidingen op niveau 6. Dit is het gevolg van het feit dat de vooropleidingen van HBO-deeltijdopleidingen worden bepaald op basis van de Onderwijsmatrix waarbij ook een klein percentage van de geslaagden op HBO-niveau als vooropleiding WO hebben.

stige arbeidsmarktinstroom van schoolverlaters uit het niet-reguliere onderwijs op VBO- en 
Uit de tabel blijkt eveneens dat verreweg de meeste niveauverhogende of richtingveranderende niet-reguliere opleidingen worden gevolgd op MBO/LLW-niveau. In 1994 hebben ruim 50.000 personen een niveauverhogende of richtingveranderende niet-reguliere opleiding op dit niveau behaald. Dit is maar liefst bijna $80 \%$ van de totale arbeidsmarktinstroom van schoolverlaters uit het niet-reguliere onderwijs in 1994. Op de arbeidsmarkt is het percentage werkenden met een MBO/LLW-achtergrond eveneens het grootst, maar daarbij gaat het slechts om een werkgelegenheidsaandeel van $44 \%$. Na de opleidingen op $\mathrm{MBO} / \mathrm{LLW}$-niveau worden de meeste niveauverhogende of richtingveranderende nietreguliere opleidingen gevolgd op achtereenvolgens VBO-, HBO-, WO- en Post-WO-niveau.

Bij de toerekening van de arbeidsmarktinstroom uit het niet-reguliere onderwijs aan de gevolgde vooropleiding blijkt dat de instroom het meest wordt toegerekend aan vooropleidingen op VBO-niveau gevolgd door opleidingen op MBO/LLW-niveau en Basisonderwijs. Deze verdeling wordt grotendeels bepaald door de instroom uit het niet-reguliere onderwijs op MBO/LLW-niveau. Van de totale instroom uit het niet-reguliere onderwijs wordt in 1994 $43 \%$ toegerekend aan een vooropleiding op VBO-niveau: 28.000 . $29 \%$ wordt toegerekend aan een vooropleiding op MBO/LLW-niveau en $23 \%$ aan Basisonderwijs. De instroom uit het niet-reguliere onderwijs die wordt toegerekend aan vooropleidingen op HBO-niveau of hoger is klein. In het algemeen geldt dat de instroom grotendeels wordt toegerekend aan een vooropleiding die één niveau lager ligt dan het niveau van de gevolgde niet-reguliere opleiding.

Tabel 2.4 geeft een meer gedetailleerd overzicht van de verdeling van de arbeidsmarktinstroom uit het niet-reguliere onderwijs naar onderwijsniveau en -richting in 1994. Van de totale instroom uit het niet-reguliere onderwijs blijkt ongeveer $28 \%$ een niveauverhogende of richtingveranderende opleiding in de techniek of wis- en natuurkunde te hebben gevolgd: 18.100 . Na de technische opleidingen worden de meeste niet-reguliere opleidingen gevolgd in de economische, administatieve en commerciële richting, namelijk ongeveer $26 \%$. Met $11 \%$ worden er eveneens relatief veel niveauverhogende of opleidingsrichtingveranderende (para)medische opleidingen gevolgd binnen het niet-reguliere onderwijs.

Als naar de verschillende opleidingsniveau's wordt gekeken, blijkt dat de verdeling over de opleidingsrichtingen per onderwijsniveau verschillen. Op VBO-niveau overheersen de algemene opleidingen (met name persoonlijke en maatschappelijke vorming (LLW) en de algemene en humaniora-opleidingen op VBO-niveau binnen het ESO en BMO) met een aandeel van $27 \%$, gevolgd door de technische opleidingen met $24 \%$, de economische, Tabel 2.4

Niveauverhogende of richtingveranderende arbeidsmarktinstroom van schoolverlaters uit het niet-regulier onderwijs naar onderwijsniveau en richting, 1994

5. De doorstroom van het WO naar het Post-WO heeft overigens geen effect op de instroomprognoses, omdat in het Informatiesysteem Onderwijs-Arbeidsmarkt van het ROA op het hoogste niveau alleen opleidingstypen op universitair niveau worden onderscheiden. 


\begin{tabular}{|c|c|c|c|c|c|}
\hline \multirow[t]{2}{*}{ Opleidingsrichting } & \multicolumn{4}{|c|}{ Opleidingsniveau } & \multirow[b]{2}{*}{ Totaal } \\
\hline & 3 & 4 & 5 & $6 / 7$ & \\
\hline \multicolumn{6}{|l|}{ Aantallen } \\
\hline Algemeen/Lerarenopleidingen & 1.800 & 1.400 & 1.300 & 200 & 4.700 \\
\hline Humaniora/Theologie & 400 & & 200 & 400 & 1.000 \\
\hline Agrarisch & 300 & 1.800 & & & 2.100 \\
\hline Techniek, wis- en natuurkunde & 1.600 & 16.100 & 300 & 100 & 18.100 \\
\hline Transport, communicatie en verkeer & 200 & 1.300 & & - & 1.500 \\
\hline (Para)medisch & & 6.200 & 1.100 & - & 7.300 \\
\hline Economisch, administatief en commercieel & 1.100 & 13.800 & 1.600 & 300 & 16.900 \\
\hline Sociaal-cultureel & & 1.000 & 800 & 1.000 & 2.900 \\
\hline Persoonlijke verzorging & 100 & 5.400 & - & - & 5.600 \\
\hline Kunst & 100 & & 200 & 100 & 400 \\
\hline Openbare orde en veiligheid & 1.000 & 3.500 & 400 & - & 4.900 \\
\hline Overig onderwijs & . & . & 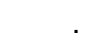 & - & . \\
\hline Totaal & 6.700 & 50.500 & 5.900 & 2.200 & 65.400 \\
\hline Relatief & $\%$ & $\%$ & $\%$ & $\%$ & $\%$ \\
\hline Algemeen/Lerarenopleidingen & 27 & 3 & 23 & 9 & 7 \\
\hline Humaniora/Theologie & 6 & 0 & 3 & 20 & 2 \\
\hline Agrarisch & 5 & 4 & 0 & 0 & 3 \\
\hline Techniek, wis- en natuurkunde & 24 & 32 & 5 & 5 & 28 \\
\hline Transport, communicatie en verkeer & 3 & 3 & 0 & - & 2 \\
\hline (Para)medisch & 0 & 12 & 18 & - & 11 \\
\hline Economisch, administatief en commercieel & 17 & 27 & 27 & 16 & 26 \\
\hline Sociaal-cultureel & 1 & 2 & 1 & 47 & 5 \\
\hline Persoonlijke verzorging & 2 & 11 & - & - & 9 \\
\hline Kunst & 2 & 0 & 3 & 3 & 1 \\
\hline Openbare orde en veiligheid & 14 & 7 & 7 & - & 8 \\
\hline Overig onderwijs & 0 & 0 & 0 & - & 0 \\
\hline Totaal & 100 & 100 & 100 & 100 & 100 \\
\hline
\end{tabular}

Bron: ROA (op basis van diverse databronnen, zie paragraaf 2.2)

administratieve en commerciële opleidingen met $17 \%$ en de openbare orde en veiligheidsopleidingen met $14 \%$.

Op MBO/LLW-niveau worden daarentegen de meeste niveauverhogende of richtingveranderende niet-reguliere opleidingen in de technische richting gevolgd: $32 \%$. Daarna komen de economische, administratieve en commerciële richtingen met een aandeel van $27 \%$ en de (para)medische richtingen met $12 \%$.

Op HBO-niveau worden de meeste niveauverhogende of richtingveranderende niet-reguliere opleidingen in de economische, administratieve en commerciële richting gevolgd. Het aandeel van deze richtingen in de totale instroom op HBO-niveau is $27 \%$. De lerarenopleidingen volgen met een aandeel van $23 \%$ en de (para)medische richtingen met $18 \%$. 
Op (Post-)WO-niveau overheersen de sociaal-culturele richtingen die goed zijn voor $47 \%$ van de niet-reguliere opleidingen, gevolgd door humaniora-richtingen met $20 \%$ en economische, administratieve en commerciële richtingen met $16 \%$.

\section{Onderwijsrekeningen}

\subsection{Inleiding}

In dit hoofdstuk wordt ingegaan op de analyse van het niet-reguliere onderwijs op basis van de Onderwijsrekeningen 1995/'96. Eerst wordt in paragraaf 3.2 nader ingegaan op de methoden die gehanteerd zijn om het reguliere voltijdonderwijs van het niet-reguliere onderwijs af te bakenen en het niveauverhogende en richtingveranderende karakter van de niet-reguliere opleidingen te bepalen. Vervolgens wordt in paragraaf 3.3 ingegaan op de omvang van de stromen in het onderwijs zoals deze in de Onderwijsrekeningen 1995/'96 zijn bepaald en enkele kenmerken van deze stromen. Daarbij wordt in het bijzonder ook een beeld geschetst van de omvang van de opleidingsniveau-verhogende of opleidingsrichting-veranderende arbeidsmarktinstroom vanuit het niet-reguliere onderwijs op basis van de Onderwijsrekeningen 1995/'96' .

In de tabellen in dit hoofdstuk en de daarop volgende hoofdstukken worden de volgende tekens gebruikt:

. $\quad$ er wordt niet voldaan aan de ondergrens voor publicatie $(<5.000)$.

- nihil.

\subsection{Opbouw om te komen tot vergelijkbare gegevens}

In de Onderwijsrekeningen zijn twee kernvariabelen opgenomen die betrekking hebben op de onderwijsachtergrond van de respondenten:

- de opleiding die men op dat moment volgt (de actuele opleiding);

- de gevolgde opleidingen.

Met de variabelen die betrekking hebben op de actuele opleiding worden verschillende kenmerken gemeten die behoren bij de opleiding of cursus die de respondenten op het moment van enquêteren volgt. Op basis van deze informatie wordt het aantal onderwijsvolgenden in het schooljaar 1995/'96 bepaald. In de Onderwijsrekeningen worden alleen de personen die een opleiding met een opleidingsduur van ten minste 6 maanden volgen, meegeteld.

Tabel 3.1 geeft een overzicht van de onderwijsvolgenden van 15 jaar en ouder in de Onderwijsrekeningen naar onderwijsniveau en hoogst behaalde vooropleiding. In het

6. In het vervolg van dit werkdocument zal kortweg van Onderwijsrekeningen worden gesproken. 
schooljaar 1995/'96 volgden in totaal 4,2 miljoen personen een opleiding met een duur van minstens 6 maanden (CBS, 1996). Van deze 4,2 miljoen onderwijsvolgenden waren er bijna 2,2 miljoen 15 jaar of ouder. Bijna de helft van deze onderwijsvolgenden volgde een opleiding op MBO/LLW-niveau: 970.000. Daarna werden er de meeste opleidingen op VBO-niveau gevolgd, namelijk 575.000. De hoogst behaalde vooropleidingen van de onderwijsvolgden liggen, zoals verwacht kan worden, voor het merendeel één opleidingsniveau lager dan het opleidingsniveau van de actuele opleiding.

Tabel 3.1

Onderwijsvolgenden 15 jaar en ouder in de Onderwijsrekeningen naar opleidingsniveau en hoogst behaalde vooropleiding, 1995/'96

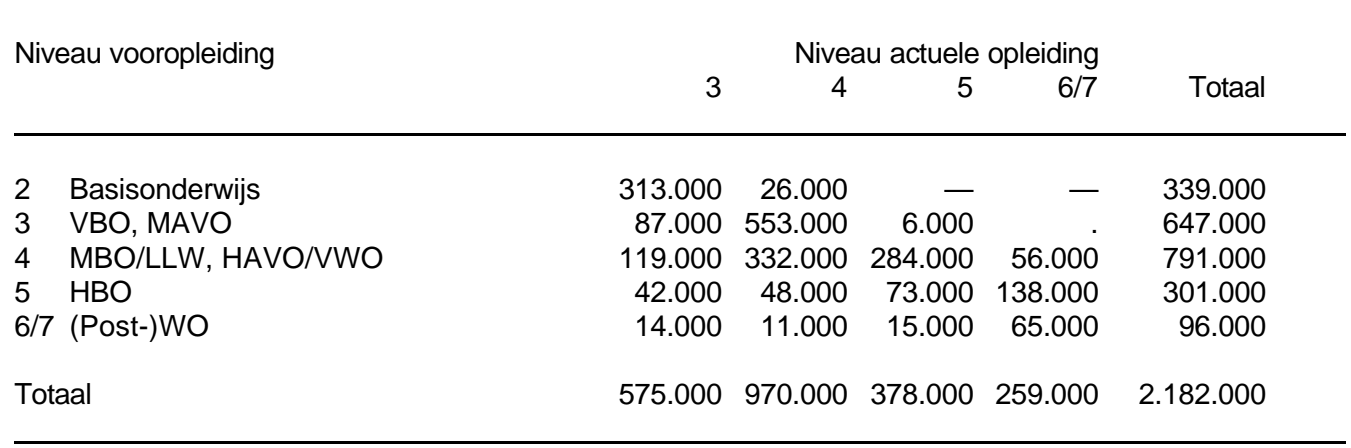

Bron: OR/ROA

Van de actuele opleiding, de opleiding die men op het moment van enquêteren volgt, is echter niet bekend of men deze opleiding met succes zal afronden. Eveneens is niet bekend of er sprake zal zijn van een verandering van het kwalificatieprofiel, met andere woorden: de mate waarin het behalen van de actuele opleiding de hoogst behaalde opleiding verandert. Er zouden dus veronderstellingen moeten worden gemaakt over het slaagpercentage en de mate waarin het kwalificatieprofiel zal veranderen, veronderstellingen die, zoals in hoofdstuk 2 werd aangegeven, ook in de huidige methodiek van de arbeidsmarktinstroomprognoses worden gemaakt. De gegevens over de actuele opleiding van de respondenten geven derhalve niet de benodigde gegevens om het niveauverhogende of opleidingsrichting-veranderende karakter van de niet-reguliere opleiding te bepalen.

De gegevens met betrekking tot de gevolgde opleidingen die aan de EBB worden ontleend bieden duidelijk meer mogelijkheden. Aan de respondenten wordt gevraagd welke opleidingen met een opleidingsduur van meer dan 6 maanden zij na het basisonderwijs hebben gevolgd. En van deze opleidingen (maximaal 6 ) wordt onder andere eveneens gevraagd:

- wanneer men met de opleiding is begonnen;

- wanneer men de opleiding heeft beëindigd;

- de duur van de opleiding;

- of men de opleiding in deeltijd of voltijd heeft gevolgd;

- of men de opleiding met diploma heeft afgerond;

- de naam van de (soort) opleiding. 
Op basis van de naam van de opleiding wordt zowel de SOI-5-digit code als het identificatienummer bepaald die bij de opleiding behoren. De SOI-5-digit code is een 5 cijferige opleidingscode, waarbij soortgelijke opleidingen dezelfde code krijgen. Daarnaast krijgt iedere opleiding een uniek identificatienummer. Op basis van de SOI-5-digit code en het identificatienummer kan iedere opleiding op het laagst mogelijke aggregratieniveau worden gecodeerd. Het verder verbijzonderen van de SOl-5-digit indeling op basis van de indentificatienummers heeft het grote voordeel dat de leerlingwezenopleidingen onderscheiden kunnen worden van de verwante reguliere MBO-opleidingen.

Naast de informatie over de gevolgde opleidingen wordt gebruik gemaakt van de gegevens over de hoogst behaalde opleiding van de respondenten. Deze hoogst behaalde opleiding wordt bepaald op basis van de gevolgde opleidingen van de respondenten. De informatie die idealiter beschikbaar zou moeten zijn over de gevolgde niet-reguliere opleiding is op basis van bovenstaande aspecten van de gevolgde opleidingen te bepalen?:

- het opleidingstype waartoe de opleiding gerekend kan worden: SOI-5-digit code en identificatienummer;

- het behalen van het diploma;

- de vooropleiding;

- of er sprake is van een verandering van het kwalificatieprofiel: vergelijking (hoogst behaalde) vooropleiding en de gevolgde opleiding.

Van de gevolgde opleiding is echter niet bekend of deze opleiding een reguliere voltijd- of een niet-reguliere opleiding is. In de Onderwijsrekeningen dient het reguliere voltijdonderwijs van het niet-reguliere onderwijs te worden afgebakend. Allereerst zijn hiervoor de leerlingwezenopleidingen op basis van het identificatienummer geselecteerd. Het overige niet-reguliere onderwijs is vervolgens afgebakend van het reguliere voltijdonderwijs op basis van een geamendeerd afleidingsschema van het CBS. Een opleiding op het desbetreffende opleidingsniveau is getypeerd als een reguliere voltijdopleiding als de gediplomeerden aan de voorwaarden voldoen die in tabel 3.2 worden gegeven. Indien dat niet het geval is, wordt een opleiding als niet-reguliere opleiding gedefinieerd.

Op één punt wordt echter van de door het CBS gehanteerde afbakening afgeweken. Een opleiding op WO-niveau wordt door het CBS als een voltijdopleiding beschouwd, als de leeftijd van de student tussen de 22 en 65 jaar ligt en de opleidingsduur van de studie 4 jaar of meer is. Ons inziens, heeft dit als nadeel dat bijvoorbeeld de geslaagden van de Open Universiteit en de NIVRA-opleidingen ten onrechte tot de gediplomeerden van het reguliere voltijdonderwijs worden gerekend. Voor dit onderzoek wordt een WO-opleiding daarom dan ook als voltijdopleiding gedefinieerd als de leeftijd van de student tussen de 22 en 31 jaar ligt en de opleidingsduur 4 jaar of meer is. Door de leeftijdscategorie te beperken tot de afgestudeerden van 22 tot 31 jaar behoren 3.000 geslaagde voltijders

7. De gegevens die voor dit onderzoek worden gebruikt zijn in feite afkomstig uit de EBB. Omdat door ons gebruik is gemaakt van het bestand van de Onderwijsrekeningen zal toch steeds bij de bronverwijzing van Onderwijsrekeningen worden gesproken in plaats van EBB. 
volgens de CBS-afbakening in dit onderzoek tot het niet-reguliere onderwijs.

Tabel 3.2

Voorwaarden waaraan moet worden voldaan om een opleiding als reguliere voltijdopleiding te definiëren (leeftijd en opleidingsduur).

$\begin{array}{ll}\text { MAVO } & \leq 19 \text { jaar } \\ \text { VBO } & \leq 20 \text { jaar } \\ \text { HAVO } & \leq 19 \text { jaar } \\ \text { VWO } & \leq 20 \text { jaar } \\ \text { MBO } & <24 \text { jaar en opleidingsduur } \geq 3 \text { jaar } \\ \text { HBO } & \geq 21 \text { en }<30 \text { jaar en opleidingsduur } \geq 3 \text { jaar } \\ \text { WO } & \geq 22 \text { en } \leq 30 \text { jaar en opleidingsduur } \geq 4 \text { jaar }\end{array}$

Op deze wijze resulteren de gevolgde niet-reguliere opleidingen. Vervolgens worden de niet-reguliere opleidingen die men met goed gevolg heeft voltooid geselecteerd. Op basis van het jaar waarin men de opleiding heeft voltooid, wordt het aantal gediplomeerden van de niet-reguliere opleidingen in het desbetreffende jaar bepaald. Als uitgangspunt voor de analyse is gekozen voor het aantal gediplomeerden van het niet-reguliere onderwijs in het jaar 1994. Dit is het meest recente kalenderjaar waarvoor voor alle geënqueteerden gegevens over het volledige jaar beschikbaar zijn.

Er zijn twee voordelen om dit jaar als uitgangspunt te nemen. Ten eerste geeft dit een zo actueel mogelijk inzicht in de invloed van het niet-reguliere onderwijs op het kwalificatieprofiel. Ten tweede kan de vooropleiding op een relatief eenvoudige wijze en met meer zekerheid worden bepaald. De hoogst behaalde opleiding zou alleen nog beïnvloed kunnen zijn door opleidingen die in 1995 of in 1996 zijn voltooid. Als dit het geval is en de hoogst behaalde opleiding heeft een hoger opleidingsniveau of een andere opleidingsrichting dan de in 1994 behaalde niet-reguliere opleiding, kan niet meer met zekerheid worden gezegd of de in 1994 voltooide niet-reguliere opleiding het kwalificatieprofiel dat de persoon toen had, heeft veranderd.

Van de in 1994 voltooide niet-reguliere opleidingen wordt vervolgens bepaald of deze niveauverhogend of opleidingsrichting-veranderend zijn. Daarbij kan zich een zevental mogelijkheden voordoen:

A. Het niveau van de hoogst behaalde opleiding is hoger dan het niveau van de in 1994 behaalde niet-reguliere opleiding.

1. hoogst behaalde niveau wordt bepaald door een opleiding behaald in 1995 of 1996.

2. hoogst behaalde niveau is vóór 1994 behaald; de in 1994 behaalde niet-reguliere opleiding is niet niveauverhogend geweest.

B. Het niveau van de hoogst behaalde opleiding is gelijk aan het niveau van de in 1994 
behaalde niet-reguliere opleiding

B1. De hoogst behaalde opleiding en de in 1994 behaalde niet-reguliere opleiding hebben dezelfde SOI-5-digit code.

3. hoogst behaalde niveau is vóór 1994 behaald; de in 1994 behaalde niet-reguliere opleiding leidt niet tot een kwalificatieverandering.

4. hoogst behaalde niveau wordt bepaald door een opleiding behaald in 1995 of 1996.

5. hoogst behaalde niveau is in 1994 behaald; de in 1994 behaalde niet-reguliere opleiding is de hoogst behaalde opleiding.

B2. De hoogst behaalde opleiding en de in 1994 behaalde niet-reguliere opleiding hebben niet dezelfde SOI-code, maar wel hetzelfde opleidingsniveau (andere opleidingsrichting)

6. hoogst behaalde richting wordt bepaald door een opleiding behaald in 1995 of 1996 .

7. hoogst behaalde opleidingsrichting is vóór 1994 behaald; de in 1994 behaalde nietreguliere opleiding is door het CBS niet als kwalificatieveranderend beschouwd.

Bij de mogelijkheden 1, 4, 5 en 6 (hoogst behaalde opleiding is bepaald door de behaalde niet-reguliere opleiding in 1994 of door een opleiding die voltooid is in 1995 of 1996) is vervolgens bepaald wat de vooropleiding is. Daarvoor zijn per respondent de gevolgde opleidingen in oplopende volgorde van het jaar van het behalen van het diploma gesorteerd. Uitgaande van het jaar 1994 wordt gekeken naar de opleiding die vóór deze opleiding is voltooid. Als deze opleiding een lager opleidingsniveau heeft dan de in 1994 behaalde niet-reguliere opleiding dan wordt deze opleiding de vooropleiding. Deze veronderstelling kan een onderschatting inhouden van het richtingveranderende karakter van de niet-reguliere opleidingen omdat er geen rekening wordt gehouden met richtingveranderende opleidingen.

Bij de mogelijkheden 2, 3 en 7 is de hoogst behaalde opleiding bepaald door een opleiding die vóór 1994 is behaald. De in 1994 behaalde niet-reguliere opleiding is niet niveauverhogend of richtingveranderend geweest.

\subsection{Niet-regulier onderwijs naar onderwijsniveau, -richting en vooropleiding}

Op basis van de in tabel 3.2 aangegeven criteria is het reguliere voltijdonderwijs van het niet-reguliere onderwijs (LLW en overig niet-regulier onderwijs) afgebakend. Tabel 3.3 geeft een overzicht van het aantal gediplomeerden van het regulier voltijd- en het nietregulier onderwijs op basis van deze afbakening. Uit de tabel blijkt dat in 1994 in totaal ruim 500.000 personen een opleiding met goed gevolg voltooid hebben. Hiervan hebben ruim 280.000 personen een reguliere voltijdopleiding voltooid, terwijl ruim 240.000 personen een niet-reguliere opleiding hebben voltooid. Deze cijfers laten zien dat het nietreguliere onderwijs qua aantal geslaagden niet veel onderdoet voor het reguliere voltijdonderwijs.

Als naar de verschillende opleidingsniveau's wordt gekeken blijkt echter dat er op de meeste opleidingsniveau's duidelijk minder niet-reguliere opleidingen worden voltooid dan 
reguliere voltijdopleidingen. Met name de algemene opleidingen, MAVO, HAVO en VWO, worden veel minder vaak niet-regulier dan in voltijd gevolgd. De grote uitzondering zijn de opleidingen op MBO/LLW-niveau. Er blijken ongeveer drie keer zoveel niet-reguliere opleidingen op dit niveau te zijn voltooid dan reguliere voltijdopleidingen. In 1994 zijn er in totaal 23.000 personen die een diploma behaalden van een LLW-opleiding. Hiervan behaalt bijna iedereen, namelijk 22.000 personen, een diploma van een LLW-opleiding die getypeerd is op opleidingsniveau 4. Het resterende deel van de gediplomeerden heeft een LLW-opleiding behaald die op opleidingsniveau 3 is ingedeeld (voorbeelden zijn de primaire leerlingwezenopleidingen op horeca-gebied (o.a. leerling kok, gastvrouw/gastheer), dakdekker en consumptieve technieken (o.a. leerling slager, leerling verkoopmedewerk(st)er, assistent chocolatier, werknemer (pluimvee-) vleesverwerkende industrie).

Tabel 3.3

Aantal gediplomeerden regulier voltijd- en niet-regulier onderwijs naar onderwijsniveau, 1994

\begin{tabular}{lrrr}
\hline Opleidingsniveau & Regulier voltijd & Niet-regulier & Totaal \\
\hline 3 VBO, MAVO & 95.000 & 35.000 & 130.000 \\
MAVO & 52.000 & 32.000 & 56.000 \\
VBO & 43.000 & 75.000 \\
4 MBO/LLW, HAVO/VWO & 124.000 & 162.000 & 286.000 \\
HAVO/VWO & 74.000 & 11.000 & 85.000 \\
MBO & 49.000 & 129.000 & 179.000 \\
LLW & n.v.t. & 22.000 & 22.000 \\
5 HBO & 43.000 & 35.000 & 78.000 \\
6 WO & 20.000 & 10.000 & 29.000 \\
Totaal (incl. Post-WO) & 281.000 & 243.000 & 524.000 \\
\hline Bron: OR/ROA & & & \\
\hline
\end{tabular}

Bron: OR/ROA

In tabel 3.4 wordt een overzicht gegeven van de ontwikkelingen in de tijd. De tabel geeft een beeld van het aantal gediplomeerden van het regulier voltijd- en het niet-regulier onderwijs in de jaren 1990 tot en met 1995, verbijzonderd naar onderwijsniveau. Het aantal gediplomeerden van de reguliere voltijdopleidingen blijkt in de periode 1990-1995 gestaag af te nemen van 325.000 tot 273.000 gediplomeerden. Als naar de onderscheiden opleidingsniveau's wordt gekeken blijkt dat deze afname zich vooral voordoet bij de opleidingen op MBO/LLW-niveau of lager, hoewel er de laatste jaren ook sprake is van een dalend aantal geslaagden op HBO-niveau.

Het aantal gediplomeerden van de niet-reguliere opleidingen laat in de periode 1990-1995 een wisselend beeld zien. Evenals het aantal gediplomeerden van de reguliere voltijdopleidingen blijkt het aantal gediplomeerden van de niet-reguiliere opleidingen de laatste jaren 
af te nemen van 249.000 in 1993 tot 227.000 gediplomeerden in 1995. Met name het aantal gediplomeerden van de niet-reguliere opleidingen op VBO/MAVO- en MBO-niveau neemt de laatste jaren af. Daarentegen neemt het aantal gediplomeerden van de nietreguliere opleidingen op (Post-)WO-niveau toe. Het aandeel van de gediplomeerden van het LLW in het totaal aantal gediplomeerden van het niet-reguliere onderwijs op MBO/LLW-niveau schommelt rond de $12 \%$.

Tabel 3.4

Aantal gediplomeerden regulier voltijd- en niet-regulier onderwijs naar onderwijsniveau, 1990-1995

\begin{tabular}{|c|c|c|c|c|c|c|c|}
\hline \multicolumn{8}{|c|}{ Opleidingsniveau* } \\
\hline & 3 & 4 & 4 & 4 & & $6 / 7$ & Totaal \\
\hline MAVO & VBO & $\begin{array}{l}\text { HAVO } \\
\text { VWO }\end{array}$ & MBO & LLW & HBO & $\begin{array}{r}\text { (Post-) } \\
\text { WO }\end{array}$ & \\
\hline
\end{tabular}

Regulier voltijdonderwijs

$\begin{array}{lllllllll}1990 & 61.000 & 61.000 & 82.000 & 66.000 & \text { n.v.t. } & 37.000 & 19.000 & 325.000 \\ 1991 & 62.000 & 52.000 & 78.000 & 62.000 & \text { n.v.t. } & 38.000 & 17.000 & 310.000 \\ 1992 & 55.000 & 47.000 & 77.000 & 51.000 & \text { n.v.t. } & 39.000 & 23.000 & 292.000 \\ 1993 & 55.000 & 49.000 & 68.000 & 54.000 & \text { n.v.t. } & 44.000 & 18.000 & 287.000 \\ 1994 & 52.000 & 43.000 & 74.000 & 49.000 & \text { n.v.t. } & 43.000 & 20.000 & 281.000 \\ 1995 & 50.000 & 52.000 & 67.000 & 47.000 & \text { n.v.t. } & 40.000 & 18.000 & 273.000\end{array}$

Niet-regulier onderwijs

$\begin{array}{lrrrrrrr}1990 & 31.000 & 11.000 & 140.000 & 17.000 & 35.000 & 10.000 & 243.000 \\ 1991 & 32.000 & 11.000 & 143.000 & 19.000 & 40.000 & 9.000 & 253.000 \\ 1992 & 29.000 & 10.000 & 136.000 & 21.000 & 38.000 & 8.000 & 242.000 \\ 1993 & 36.000 & 7.000 & 138.000 & 19.000 & 41.000 & 8.000 & 249.000 \\ 1994 & 35.000 & 11.000 & 129.000 & 22.000 & 35.000 & 11.000 & 243.000 \\ 1995 & 27.000 & 7.000 & 124.000 & 17.000 & 37.000 & 14.000 & 227.000\end{array}$

Bron: OR/ROA

* Bij het niet-reguliere onderwijs worden de geslaagden MAVO en VBO samengevoegd omdat het jaarlijks aantal geslaagden van het deeltijds MAVO kleiner is dan 5.000 .

Tabel 3.5

Aantal gediplomeerden uit het niet-regulier onderwijs naar onderwijsniveau en vooropleiding, $1994^{*}$

\begin{tabular}{|c|c|c|c|c|c|}
\hline \multirow[t]{2}{*}{ Vooropleiding } & \multicolumn{4}{|c|}{ Opleidingsniveau } & \multirow[b]{2}{*}{ Totaa } \\
\hline & 3 & 4 & 5 & $6 / 7$ & \\
\hline 2 Basisonderwijs & 5.000 & 8.000 & . & - & 13.000 \\
\hline $\begin{array}{l}3 \text { VBO, MAVO } \\
\text { w.v. } \quad \begin{array}{l}\text { zelfde soi } \\
\text { niet richtingveranderend }\end{array}\end{array}$ & $\begin{array}{r}11.000 \\
.\end{array}$ & 48.000 & . & . & 61.000 \\
\hline
\end{tabular}




\begin{tabular}{|c|c|c|c|c|c|c|}
\hline $\begin{array}{c}4 \mathrm{MBO} / \mathrm{L} \\
\text { w.v. }\end{array}$ & $\begin{array}{l}\text { LW, HAVO/VWO } \\
\text { zelfde soi } \\
\text { niet richtingveranderend } \\
\text { richtingveranderend }\end{array}$ & 16.000 & $\begin{array}{l}91.000 \\
22.000 \\
31.000 \\
\mathbf{3 8 . 0 0 0}\end{array}$ & 13.000 & . & 123.000 \\
\hline $\begin{array}{r}5 \mathrm{HBO} \\
\text { w.v. }\end{array}$ & $\begin{array}{l}\text { zelfde soi } \\
\text { niet richtingveranderend } \\
\text { richtingveranderend }\end{array}$ & 2.000 & 12.000 & $\begin{array}{r}16.000 \\
6.000 \\
5.000\end{array}$ & 5.000 & 35.000 \\
\hline $\begin{array}{c}6 \text { WO } \\
\text { W.v. }\end{array}$ & $\begin{array}{l}\text { zelfde soi } \\
\text { niet richtingveranderend } \\
\text { richtingveranderend }\end{array}$ & . & . & 5.000 & $\cdot$ & 10.000 \\
\hline Totaal (i & רcl. Post-WO) & 35.000 & 162.000 & 35.000 & 10.000 & 243.000 \\
\hline
\end{tabular}

Tabel 3.5 geeft het aantal gediplomeerden van het niet-reguliere onderwijs in 1994, verbijzonderd naar onderwijsniveau van de behaalde niet-reguliere opleiding en de hoogst voltooide vooropleiding. De hoogst voltooide vooropleidingen zijn bepaald op basis van de methodiek die in paragraaf 3.2 is beschreven. Wanneer de in 1994 behaalde niet-reguliere opleiding op een hoger niveau ligt dan de vooropleiding is er sprake van een niveauverhogende niet-reguliere opleiding. Wanneer de niet-reguliere opleiding hetzelfde opleidingsniveau heeft als de vooropleiding worden drie mogelijkheden onderscheiden:

- zelfde SOI: de behaalde niet-reguliere opleiding heeft dezelfde SOI-code als de hoogst behaalde vooropleiding. De niet-reguliere opleiding is niet niveauverhogend of richtingveranderend.

- niet richtingveranderend: de behaalde niet-reguliere opleiding heeft een andere opleidingsrichting dan de hoogst behaalde vooropleiding, maar deze richtingverandering wordt niet relevant geacht voor het beroep dat men uitoefent. De niet-reguliere opleiding is niet niveauverhogend of richtingveranderend.

- richtingveranderend: de behaalde niet-reguliere opleiding heeft een andere opleidingsrichting dan de hoogst behaalde vooropleiding. De niet-reguliere opleiding is derhalve richtingveranderend.

Uit de tabel blijkt dat in 1994 van het totaal aantal gediplomeerden van het niet-reguliere onderwijs ongeveer de helft een vooropleiding op MBO/LLW-niveau heeft. Als naar het opleidingsniveau van de gevolgde niet-reguliere opleidingen wordt gekeken valt op dat bij de opleidingen op VBO-niveau iets meer dan de helft van de gediplomeerden een vooropleiding op MBO/LLW-niveau of hoger heeft. Het gaat hier om het volgen van cursussen (bijvoorbeeld cursussen vreemde talen) die ook open staan voor lager opgeleiden. Van degenen met een opleiding op VBO-niveau volgt meer dan de helft geen richtingveranderende niet-reguliere opleiding. Al met al is van de in totaal 35.000 personen die in 1994 een niet-reguliere opleiding op VBO-niveau hebben voltooid bij 10.000 personen sprake 
van een niveauverhogende of richtingveranderende opleiding, dat is $29 \%$ van het totaal aantal gediplomeerden met een niet-reguliere opleiding op VBO-niveau.

In het algemeen geldt dat met het toenemen van het opleidingsniveau van de niet-reguliere opleidingen ook het percentage dat niveauverhogend of richtingveranderend is toeneemt.

Bij 95.000 van de 162.000 gediplomeerden van de niet-reguliere opleidingen op $\mathrm{MBO} /$ LLW-niveau is de opleiding niveauverhogend of richtingveranderend (59\%). Bij 56.000 gediplomeerden is er sprake van een verhoging van het opleidingsniveau, terwijl bij 38.000 personen de niet-reguliere opleiding richtingveranderend is.

Voor de niet-reguliere opleidingen op HBO-niveau geldt dat 56\% niveauverhogend of richtingveranderend van karakter is. Van de 16.000 gediplomeerden waarvoor de vooropleiding eveneens op HBO-niveau ligt, is voor 5.000 personen de niet-reguliere opleiding richtingveranderend.

De niet-reguliere opleidingen op WO- en Post-WO-niveau zijn in het merendeel niveauverhogend of richtingveranderend. Van de in 1994 behaalde niet-reguliere opleidingen op WO-niveau is dit $89 \%$, terwijl dit voor de niet-reguliere Post-WO-opleidingen zelfs $92 \%$ is ${ }^{8}$.

In tabel 3.6 wordt per opleidingsniveau een overzicht gegeven van de niet-reguliere opleidingen die niveauverhogend of richtingveranderend zijn. In totaal zijn 134.000 niet-reguliere opleidingen die in 1994 met goed gevolg zijn afgerond niveauverhogend of richtingveranderend van karakter. Dit is $55 \%$ van alle in 1994 voltooide niet-reguliere opleidingen. Van alle niveauverhogende of richtingveranderende niet-reguliere opleidingen worden er 95.000 op MBO/LLW-niveau voltooid, 20.000 op HBO-niveau en circa 10.000 op VBO- en WO-niveau.

Tabel 3.6

Aantal niveauverhogende en richtingveranderende gediplomeerden uit het niet-regulier onderwijs naar onderwijsniveau en vooropleiding, 1994

\begin{tabular}{|c|c|c|c|c|c|c|}
\hline \multirow[t]{2}{*}{ Vooropleiding } & \multicolumn{6}{|c|}{ Opleidingsniveau } \\
\hline & 3 & 4 & 5 & 6 & 7 & Totaal \\
\hline 2 Basisonderwijs & 5.000 & 8.000 & . & - & - & 13.000 \\
\hline 3 VBO, MAVO & 5.000 & 48.000 & & . & - & 55.000 \\
\hline 4 MBO/LLW, HAVO/VWO & & 38.000 & 13.000 & & - & 53.000 \\
\hline $5 \mathrm{HBO}$ & & & 5.000 & 5.000 & 一 & 11.000 \\
\hline $6 \mathrm{WO}$ & & & & & . & \\
\hline
\end{tabular}

8. Voor het overgrote deel ligt de vooropleiding bij de niet-reguliere opleidingen op (Post-) WO-niveau reeds op universitair niveau. Daar in het Informatiesysteem Onderwijs-Arbeidsmarkt geen onderscheid tussen het WO- en het Post-WO-niveau wordt gemaakt, heeft deze niveauverhoging geen invloed op de arbeidsmarktprognoses. 
Bron: OR/ROA

Als het leerlingwezen afzonderlijk wordt bekeken, blijkt dat voor $71 \%$ van de gediplomeerden deze niet-reguliere opleiding niveauverhogend of richtingveranderend van aard is. Dit komt overeen met circa 16.000 gediplomeerden. Voor 6.000 gediplomeerden is de in 1994 behaalde LLW-opleiding niet niveauverhogend of richtingveranderend geweest. Het gaat hier vooral om gediplomeerden van de secondaire LLW-opleidingen die al een vooropleiding op MBO/LLW-niveau hadden.

In tabel 3.7 worden degenen die in 1994 een diploma behaalde van een niet-reguliere opleiding verbijzonderd naar opleidingsniveau en leeftijdsklasse. Zoals in hoofdstuk 2 reeds aangegeven is, wordt bij de huidige methodiek van de arbeidsmarktinstroomprognose bij het niet-reguliere onderwijs vaak verondersteld dat alleen voor personen van 30 jaar of jonger de niet-reguliere opleidingen een niveauverhogend of richtingveranderend karakter heeft.

De tabel laat zien dat het merendeel van de geslaagden van het niet-reguliere onderwijs 30 jaar of jonger is. Daarnaast zijn er 64.000 geslaagden in de leeftijd van 31-40 jaar en 38.000 geslaagden ouder dan 40 jaar. Met het toenemen van de leeftijd van de geslaagden blijkt inderdaad dat het aandeel van de geslaagden waarvoor de niet-reguliere opleiding niveauverhogend of richtingveranderend is, afneemt. Voor de gediplomeerden die 20 jaar of jonger zijn is de niet-reguliere opleiding in $84 \%$ niveauverhogend of richtingveranderend. Echter, bij 31 tot 40 jarigen is er toch nog bij $50 \%$ van de geslaagden sprake van een niveauverhogende of richtingveranderende niet-reguliere opleiding. Bij de gediplomeerden van 40 jaar of ouder is dit gelijk aan $46 \%$. Vooral bij de gediplomeerden op hoger en middelbaar niveau blijkt er ook bij degenen die ouder zijn dan 30 nog vaak sprake te zijn van een niveauverhogende of richtingveranderende niet-reguliere opleiding.

Tabel 3.8 geeft een samenvattend beeld van het aantal gediplomeerden van 30 jaar of jonger dat in 1994 een niveauverhogende of opleidingsrichting-veranderende niet-reguliere opleiding heeft gevolgd en hun aandeel in het totaal aantal niveauverhogende of richtingTabel 3.7

Aantal (niveauverhogende en richtingveranderende) gediplomeerden uit het niet-regulier onderwijs naar onderwijsniveau, vooropleiding en leeftijdsklasse, 1994*

\begin{tabular}{|c|c|c|c|c|}
\hline \multirow{2}{*}{ Vooropleiding } & \multicolumn{3}{|c|}{ Leeftijd in jaren } & \\
\hline & $\begin{array}{l}\leq 20 \\
\text { jaar }\end{array}$ & $\begin{array}{rr}21-30 & 31-40 \\
\text { jaar } & \text { jaar }\end{array}$ & $\begin{array}{l}>40 \\
\text { jaar }\end{array}$ & Totaal \\
\hline
\end{tabular}

\section{VBO, MAVO}

2 Basisonderwijs

3 VBO, MAVO

zelfde soi

niet richtingveranderend

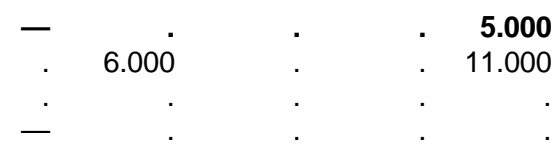


richtingveranderend

$4 \mathrm{MBO} / \mathrm{LLW}, \mathrm{HAVO} / \mathrm{VWO}$

$5 \mathrm{HBO}$

$6 \mathrm{WO}$

7 Post WO

Totaal

niveauverhogend/richtingveranderend
percentage niveauverhogend/richtingveranderend

$17.000 \quad 10.000$

$8.000 \quad 35.000$

6.000

$29 \%$

$34 \% \quad 27 \%$

10.000

\section{MBO/LLW, HAVO/VWO}

2 Basisonderwijs

3 VBO, MAVO

$4 \mathrm{MBO} / \mathrm{LLW}, \mathrm{HAVO} / \mathrm{WWO}$

zelfde soi

niet richtingveranderend

richtingveranderend

$5 \mathrm{HBO}$

$6 \mathrm{WO}$

7 Post WO

Totaal

niveauverhogend/richtingveranderend

percentage niveauverhogend/richtingveranderend

$\begin{array}{rrrrr}\mathbf{1 9 . 0 0 0} & \mathbf{1 7 . 0 0 0} & \mathbf{7 . 0 0 0} & \mathbf{5 . 0 0 0} & \mathbf{8 8 . 0 0 0} \\ 8.000 & 48.000 & 22.000 & 13.000 & 91.000 \\ . & 13.000 & 5.000 & . & 22.000 \\ . & \mathbf{1 4 . 0 0 0} & \mathbf{8 . 0 0 0} & \mathbf{6 . 0 0 0} & \mathbf{3 1 . 0 0 0} \\ . & 21.000 & 9.000 & 5.000 & 38.000 \\ . & . & 5.000 & . & 12.000 \\ - & . & . & . & . \\ - & - & - & - & - \\ 31.000 & 73.000 & 37.000 & 21.000 & 162.000 \\ \mathbf{2 5 . 0 0 0} & \mathbf{4 0 . 0 0 0} & \mathbf{1 8 . 0 0 0} & \mathbf{1 1 . 0 0 0} & \mathbf{9 5 . 0 0 0} \\ 82 \% & 55 \% & 48 \% & 54 \% & 59 \%\end{array}$

5 HBO

2 Basisonderwijs

3 VBO, MAVO

$4 \mathrm{MBO} / \mathrm{LLW}, \mathrm{HAVO} / \mathrm{VWO}$

$5 \mathrm{HBO}$

zelfde soi

niet richtingveranderend

richtingveranderend

6 WO

7 Post WO

Totaal

niveauverhogend/richtingveranderend

percentage niveauverhogend/richtingveranderend

$\begin{array}{rrrrr}- & - & - & . & . \\ . & 6.000 & . & - & . \\ - & . & 7.000 & 5.000 & 16.000 \\ - & . & . & . & 5.000 \\ - & . & . & . & 6.000 \\ - & . & . & . & 5.000 \\ - & . & . & . & 5.000 \\ - & - & . & - & . \\ . & 12.000 & 14.000 & 7.000 & 35.000 \\ . & 8.000 & 7.000 & . & 20.000 \\ 00 \% & 67 \% & 51 \% & 43 \% & 56 \%\end{array}$

Tabel 3.7 (vervolg)

Aantal (niveauverhogende en richtingveranderende) gediplomeerden uit het niet-regulier onderwijs naar onderwijsniveau, vooropleiding en leeftijdsklasse, 1994

Vooropleiding

$\begin{array}{crrrr} & \text { Leeftijd in jaren } & & \\ \leq 20 & 21-30 & 31-40 & >40 & \text { Totaal } \\ \text { jaar } & \text { jaar } & \text { jaar } & \text { jaar } & \end{array}$

\section{WO}

2 Basisonderwijs

3 VBO, MAVO

$4 \mathrm{MBO} / \mathrm{LLW}, \mathrm{HAVO} / \mathrm{VWO}$

$5 \mathrm{HBO}$

$\begin{array}{rrrrr}- & - & - & - & - \\ - & \cdot & - & - & . \\ - & . & . & . & 5.000\end{array}$


6 WO

zelfde soi

niet richtingveranderend

richtingveranderend

7 Post WO

Totaal

niveauverhogend/richtingveranderend

percentage niveauverhogend/richtingveranderend

5.000
-6.000

10.000

$-\quad 6.000$
$-\quad 95 \%$

9.000

Totaal (incl. Post-WO)

2 Basisonderwijs

3 VBO, MAVO

zelfde soi

niet richtingveranderend

niveauverhogend/richtingveranderend

$4 \mathrm{MBO} / \mathrm{LLW}, \mathrm{HAVO} / \mathrm{VWO}$

zelfde soi

niet richtingveranderend

niveauverhogend/richtingveranderend

$5 \mathrm{HBO}$

zelfde soi

niet richtingveranderend

niveauverhogend/richtingveranderend

$6 \mathrm{WO}$

zelfde soi

niet richtingveranderend

niveauverhogend/richtingveranderend

7 Post WO

zelfde soi

niet richtingveranderend

niveauverhogend/richtingveranderend

Totaal

niveauverhogend/richtingveranderend

percentage niveauverhogend/richtingveranderend

$\begin{array}{rrrrr}20.000 & 23.000 & 10.000 & 8.000 & 61.000 \\ . & . & . & . & . \\ - & . & . & . & . \\ 20.000 & 20.000 & 9.000 & 6.000 & 55.000 \\ 9.000 & 63.000 & 33.000 & 18.000 & 123.000 \\ . & 13.000 & 5.000 & . & 22.000 \\ . & 22.000 & 13.000 & 9.000 & 47.000 \\ . & 28.000 & 14.000 & 7.000 & 53.000 \\ . & 12.000 & 15.000 & 8.000 & 35.000 \\ - & . & . & . & 5.000 \\ . & 7.000 & 9.000 & . & 20.000 \\ - & 5.000 & . & . & 11.000 \\ - & . & . & . & 9.000 \\ - & - & . & - & . \\ - & . & . & . & 8.000 \\ - & . & . & . & . \\ - & . & . & . & . \\ - & - & - & - & - \\ - & - & - & . & . \\ - & . & . & - & . \\ 32.000 & 108.000 & 64.000 & 38.000 & 243.000 \\ \mathbf{2 7 . 0 0 0} & \mathbf{6 0 . 0 0 0} & \mathbf{3 2 . 0 0 0} & \mathbf{1 7 . 0 0 0} & \mathbf{1 3 4 . 0 0 0} \\ 84 \% & 56 \% & 50 \% & 46 \% & 55 \%\end{array}$

Bron: OR/ROA

* Vetgedrukte aantallen zijn niveauverhogend danwel richtingveranderend.

veranderende niet-reguliere opleidingen, verbijzonderd naar opleidingsniveau en vooropleiding.

Uit de tabel blijkt dat $65 \%$ van de personen die een niveauverhogende of richtingveranderende niet-reguliere opleiding hebben afgerond 30 jaar of jonger zijn. Dit aandeel schommelt tussen de $48 \%$ voor de niet-reguliere opleidingen op HBO-niveau en de $69 \%$ voor de niet-reguliere MBO/LLW-opleidingen. Van de in totaal 87.000 personen van 30 jaar of jonger die een niveauverhogende of richtingveranderende niet-reguliere opleiding hebben afgerond heeft maar liefst ruim driekwart een opleiding op MBO/LLW-niveau voltooid.

Tabel 3.8

Aantal en percentage niveauverhogende en richtingveranderende gediplomeerden van 30 jaar of jonger uit het niet-regulier onderwijs naar onderwijsniveau en vooropleiding, 1994 


\begin{tabular}{|c|c|c|c|c|c|}
\hline \multirow{2}{*}{ Vooropleiding } & \multicolumn{5}{|c|}{ Opleidingsniveau } \\
\hline & 3 & 4 & 5 & 6 & Totaal \\
\hline \multicolumn{6}{|l|}{ Aantal } \\
\hline 2 Basisonderwijs & . & 5.000 & - & - & 9.000 \\
\hline 3 VBO, MAVO & . & 36.000 & . & . & 40.000 \\
\hline 4 MBO/LLW, HAVO/VWO & & 24.000 & 7.000 & . & 32.000 \\
\hline $5 \mathrm{HBO}$ & & & . & . & 5.000 \\
\hline $6 \mathrm{WO}$ & & & & . & 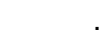 \\
\hline Totaal (WO incl. Post-WO) & 6.000 & 66.000 & 9.000 & 6.000 & 87.000 \\
\hline \multicolumn{6}{|c|}{ Als percentage van totaal aantal niveauverhogende of richtingveranderende opleidingen } \\
\hline & $\%$ & $\%$ & $\%$ & $\%$ & $\%$ \\
\hline 2 Basisonderwijs & 66 & 65 & - & - & 65 \\
\hline $3 \mathrm{VBO}, \mathrm{MAVO}$ & 50 & 75 & 71 & - & 72 \\
\hline 4 MBO/LLW, HAVO/VWO & & 64 & 54 & 47 & 61 \\
\hline $5 \mathrm{HBO}$ & & & 30 & 58 & 44 \\
\hline $6 \mathrm{WO}$ & & & & 68 & 54 \\
\hline Totaal (WO incl. Post-WO) & 57 & 69 & 48 & 58 & 65 \\
\hline
\end{tabular}

Bron: OR/ROA

In tabel 3.9 wordt een overzicht gegeven van de verdeling van de gediplomeerden van de niet-reguliere opleidingen over een aantal opleidingsrichtingen binnen de onderscheiden opleidingsniveau's.

Binnen de opleidingsniveau's VBO, MBO/LLW en HBO worden de meeste niet-reguliere opleidingen in de economische, administratieve en commerciële richting afgerond. Op VBO- en MBO/LLW-niveau komen ook de technische opleidingen vaak voor. Op HBOniveau is daarentegen het aantal gediplomeerden van de de lerarenopleidingen, de

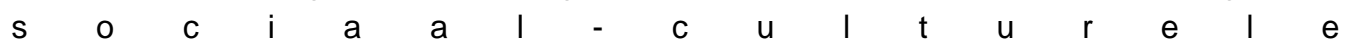
Tabel 3.9

Aantal gediplomeerden uit het niet-regulier onderwijs naar onderwijsniveau en -richting, 1994

\begin{tabular}{|c|c|c|c|c|c|}
\hline \multirow[t]{2}{*}{ Opleidingsrichting } & \multicolumn{4}{|c|}{ Opleidingsniveau } & \multirow[b]{2}{*}{ Totaal } \\
\hline & 3 & 4 & 5 & $6 / 7$ & \\
\hline \multicolumn{6}{|l|}{ Aantallen } \\
\hline Algemeen/Lerarenopleidingen & . & 12.000 & 5.000 & . & 22.000 \\
\hline Humaniora/Theologie & - & - & . & . & .000 \\
\hline Agrarisch & & 7.000 & . & . & 9.000 \\
\hline Techniek, wis- en natuurkunde & 6.000 & 39.000 & . & . & 47.000 \\
\hline Transport, communicatie en verkeer & & & & - & 8.000 \\
\hline (Para)medisch & & 12.000 & 5.000 & . & 20.000 \\
\hline
\end{tabular}


Economisch, administatief en commercieel

Sociaal-cultureel

Persoonlijke verzorging

Kunst

Openbare orde en veiligheid

Overig onderwijs

Totaal

Relatief

Algemeen/Lerarenopleidingen

Humaniora/Theologie

Agrarisch

Techniek, wis- en natuurkunde

Transport, communicatie en verkeer

(Para)medisch

Economisch, administatief en commercieel

Sociaal-cultureel

Persoonlijke verzorging

Kunst

Openbare orde en veiligheid

Overig onderwijs

Totaal

$\begin{array}{rrrrr}11.000 & 61.000 & 16.000 & . & 91.000 \\ . & . & 5.000 & . & 14.000 \\ . & 17.000 & . & - & 20.000 \\ . & . & . & . & 7.000 \\ . & . & - & - & \end{array}$

$\begin{array}{rrrrr}\% & \% & \% & \% & \% \\ 10 & 7 & 15 & 10 & 9 \\ - & - & 0 & 11 & 1 \\ 4 & 4 & 2 & 2 & 4 \\ 17 & 24 & 3 & 8 & 19 \\ 9 & 3 & 3 & - & 4 \\ 4 & 8 & 13 & 13 & 8 \\ 31 & 38 & 46 & 23 & 37 \\ 6 & 2 & 14 & 30 & 6 \\ 9 & 10 & 1 & - & 8 \\ 2 & 0 & 4 & 5 & 1 \\ 8 & 3 & - & - & 3 \\ - & 0 & - & - & 0 \\ 100 & 100 & 100 & 100 & 100\end{array}$

Bron: OR/ROA

richtingen en de (para)medische opleidingsrichtingen na de economische richtingen het grootst. De geslaagden van de niet-reguliere WO-opleidingen laten een afwijkend beeld zien. Op WO-niveau worden de meeste niet-reguliere opleidingen namelijk in de sociaalculturele richting behaald (met name de Voortgezette beroepsopleidingen), gevolgd door opleidingen in de economische, de (para)medische en de humaniora richting.

Bij de LLW-opleidingen overheersen de technische opleidingsrichtingen, gevolgd door de economiche richtingen en richtingen in de persoonlijke verzorging. Bij de gediplomeerden van de LLW-opleidingen die ingedeeld zijn op opleidingsniveau 3 domineren de opleidingen in de technische en de persoonlijke verzorgende richting (bijvoorbeeld dakdekker, consumptieve technieken en horeca).

Tabel 3.10

Aantal niveauverhogende en richtingveranderende gediplomeerden uit het niet-regulier onderwijs naar onderwijsniveau en -richting, 1994

Opleidingsrichting

Opleidingsniveau

3

$\begin{array}{llll}4 & 5 & 6 / 7 & \text { Totaal }\end{array}$

Aantallen

Algemeen/Lerarenopleidingen

12.000

Humaniora/Theologie

Agrarisch

$\begin{array}{rrrrr}. & 9.000 & . & . & 12.000 \\ - & - & . & . & 5.000\end{array}$


Techniek, wis- en natuurkunde

Transport, communicatie en verkeer

(Para)medisch

Economisch, administatief en commercieel

Sociaal-cultureel

Persoonlijke verzorging

Kunst

Openbare orde en veiligheid

Overig onderwijs

Totaal

Relatief

Algemeen/Lerarenopleidingen

Humaniora/Theologie

Agrarisch

Techniek, wis- en natuurkunde

Transport, communicatie en verkeer

(Para)medisch

Economisch, administatief en commercieel

Sociaal-cultureel

Persoonlijke verzorging

Kunst

Openbare orde en veiligheid

Overig onderwijs

Totaal

\begin{tabular}{|c|c|c|c|c|}
\hline - & 24.000 & . & . & 28.000 \\
\hline - & & . & - & 5.000 \\
\hline . & 5.000 & & . & 9.000 \\
\hline . & 30.000 & 10.000 & . & 43.000 \\
\hline . & & 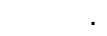 & . & 10.000 \\
\hline • & 13.000 & . & - & 15.000 \\
\hline . & - & . & . & \\
\hline 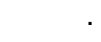 & 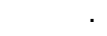 & - & - & 5.000 \\
\hline 一 & . & 一 & 一 & - \\
\hline 10.000 & 95.000 & 20.000 & 10.000 & 134.000 \\
\hline$\%$ & $\%$ & $\%$ & $\%$ & $\%$ \\
\hline 13 & 9 & 6 & 10 & 9 \\
\hline - & - & 1 & 11 & 1 \\
\hline 1 & 5 & 2 & 2 & 4 \\
\hline 24 & 25 & 3 & 8 & 21 \\
\hline 15 & 3 & 3 & - & 3 \\
\hline 1 & 6 & 8 & 13 & 7 \\
\hline 13 & 31 & 49 & 22 & 32 \\
\hline 3 & 3 & 17 & 30 & 7 \\
\hline 12 & 14 & 2 & - & 11 \\
\hline 2 & 1 & 6 & 5 & 2 \\
\hline 18 & 3 & 一 & - & 4 \\
\hline - & 1 & - & - & 1 \\
\hline 100 & 100 & 100 & 100 & 100 \\
\hline
\end{tabular}

Bron: OR/ROA

Tabel 3.10 geeft tenslotte een overzicht van het aantal gediplomeerden waarvoor de nietreguliere opleiding niveauverhogend of richtingveranderend is, verbijzonderd naar opleidingsniveau en -richting. De verdeling over de opleidingsrichtingen blijft voor de nietreguliere opleidingen op MBO/LLW-, HBO- en (Post-)WO-niveau nagenoeg hetzelfde als in tabel 3.9. Alleen op VBO-niveau verandert de verdeling over de opleidingsrichtingen. Een vergelijking met de percentages van tabel 3.9 laat zien dat op VBO-niveau vooral de economische opleidingsrichtingen vaak niet niveauverhogend of richtingveranderend zijn. Van de gediplomeerden die een niveauverhogende of richtingveranderende opleiding op VBO-niveau behalen, hebben de meeste personen (24\%) een technische opleidingsrichting gevolgd. Daarnaast heeft een relatief groot deel van de gediplomeerden een niveauverhogende of richtingveranderende opleiding in de richting 'openbare orde en veiligheid' gevolgd.

\section{Vergelijking huidige instroomprognoses met Onderwijsrekeningen}

Om een beeld te krijgen van de mogelijkheden die de Onderwijsrekeningen bieden om de kwaliteit van de prognoses van de arbeidsmarktinstroom vanuit het niet-reguliere onderwijs te verbeteren, zal in dit hoofdstuk een vergelijking worden gemaakt tussen de bij de laatste prognoses bij het bepalen van stap 2 van de arbeidsmarktinstroomprognoses gehanteerde 
aanpak en de gegevens die aan het databestand de Onderwijsrekeningen kunnen worden onttrokken. De vergelijking zal zich toespitsen op gegevens verbijzonderd naar onderwijsniveau, opleidingsrichting, vooropleiding en leeftijd.

Eerst worden de huidige prognoses voor het niet-reguliere onderwijs op een hoog aggregatieniveau vergeleken met de gegevens uit de Onderwijsrekeningen. Hierbij wordt de op basis van de huidige methodiek bepaalde niveauverhogende of richtingveranderende arbeidsmarktinstroom van schoolverlaters uit het niet-reguliere onderwijs in 1994 verbijzonderd naar onderwijsniveau en vooropleiding (tabel 2.3) vergeleken met vergelijkbare gegevens die bepaald zijn op basis van de Onderwijsrekeningen (tabel 3.6). Tabel 4.1 geeft de verschillen in aantallen personen tussen de Onderwijsrekeningen en de huidige methodiek met als basis de Onderwijsrekeningen.

Uit de tabel blijkt dat het aantal gediplomeerden waarbij sprake is van een niveauverhogende of richtingveranderende niet-reguliere opleiding op basis van de Onderwijsrekeningen in het algemeen op een hoger niveau ligt dan de arbeidsmarktinstroomprognoses zoals die bepaald is voor stap 2 bij de laatste prognoses. De tot op heden gehanteerde aanpak zou deze stroom op jaarbasis met bijna 70.000 personen onderschatten. Daarbij gaat het vanzelfsprekend om een bruto-effect omdat bepaalde stromen elkaar ten dele zullen compenseren. Zo heeft bijvoorbeeld de niveauverhogende doorstroom van VBO-opgeleiden naar MBO/LLW-niveau een positief effect op de arbeidsmarktinstroom van MBO'ers, terwijl de doorstroom van MBO'ers in het niet-reguliere onderwijs naar HBO-niveau tot een daling van de arbeidsmarktinstroom op MBO-niveau leidt. Alleen de opleidingsachtergrond ver-anderende doorstroom vanuit het basisonderwijs naar de niet-reguliere opleidingen op MBO/LLW- en VBO-niveau is bij de Onderwijsrekeningen kleiner dan de stroom die bij de prognoses is bepaald.

De grootste verschillen doen zich voor bij de doorstroom van vooropleidingen op VBO- en $\mathrm{MBO} / \mathrm{LLW}$-niveau naar niet-reguliere opleidingen op MBO/LLW-niveau. Het aantal gediplomeerden van niveauverhogende of richtingveranderende niet-reguliere opleidingen op MBO/LLW-niveau ligt in de Onderwijsrekeningen bijna 45.000 hoger dan bij de arbeidsmarktinstroomprognoses. Daarbij is in de Onderwijsrekeningen de niet-reguliere opleiding bij 25.000 personen meer richtingveranderend van aard dan in de huidige methodiek.

Tabel 4.1

Verschillen in aantal niveauverhogende en richtingveranderende gediplomeerden uit het niet-regulier onderwijs naar onderwijsniveau en vooropleiding (Aantal OR minus aantal huidige methodiek), 1994

\begin{tabular}{lrrrrrr}
\hline Vooropleiding & \multicolumn{7}{c}{ Opleidingsniveau } \\
& 3 & 4 & 5 & 6 & 7 & Totaal \\
\hline Totaal & & & & & & \\
2 Basisonderwijs & -800 & -1.000 & 100 & - & - & -1.700 \\
3 VBO, MAVO & 4.600 & 21.000 & 1.300 & 100 & - & 26.900
\end{tabular}




\begin{tabular}{|c|c|c|c|c|c|c|}
\hline $\begin{array}{l}4 \mathrm{MBO} / \mathrm{LLW}, \mathrm{HAVO} / \mathrm{VWO} \\
5 \mathrm{HBO} \\
6 \mathrm{WO} \\
7 \text { Post WO }\end{array}$ & & 24.900 & $\begin{array}{l}7.500 \\
4.800\end{array}$ & $\begin{array}{r}2.300 \\
3.900 \\
900\end{array}$ & $\begin{array}{r}- \\
-200 \\
800\end{array}$ & $\begin{array}{r}34.300 \\
8.700 \\
1.000 \\
800\end{array}$ \\
\hline Totaal & 3.400 & 44.900 & 13.700 & 7.100 & 600 & 69.600 \\
\hline \multicolumn{7}{|l|}{30 jaar of jonger } \\
\hline $\begin{array}{l}2 \text { Basisonderwijs } \\
3 \text { VBO, MAVO } \\
4 \mathrm{MBO} / L L W, \text { HAVO/VWO } \\
5 \mathrm{HBO} \\
6 \mathrm{WO} \\
7 \text { Post WO }\end{array}$ & $\begin{array}{r}-2.500 \\
2.000\end{array}$ & $\begin{array}{r}-3.800 \\
8.700 \\
11.100\end{array}$ & $\begin{array}{r}-\overline{900} \\
1.700 \\
1.000\end{array}$ & $\begin{array}{r}-\overline{100} \\
1.000 \\
1.600 \\
600\end{array}$ & $\begin{array}{r}- \\
\overline{-} \\
-400 \\
800\end{array}$ & $\begin{array}{r}-6.300 \\
11.600 \\
13.400 \\
2.600 \\
200 \\
800\end{array}$ \\
\hline Totaal & -900 & 15.900 & 3.500 & 3.200 & 400 & 22.100 \\
\hline
\end{tabular}

Bron: ROA

Uit de tabel blijkt dat op alle opleidingsniveaus het aantal gediplomeerden van de richtingveranderende niet-reguliere opleidingen in de Onderwijsrekeningen hoger ligt dan bij de arbeidsmarktinstroom in de huidige methodiek.

Als in de Onderwijsrekeningen alleen die gediplomeerden van de niveauverhogende of richtingveranderende niet-reguliere opleidingen worden meegenomen die 30 jaar of jonger zijn, blijken de verschillen tussen de gegevens uit de Onderwijsrekeningen en de gegevens van de arbeidsmarktinstroomprognoses veel kleiner te zijn. Ook in dit geval wordt het grootste verschil waargenomen bij de niet-reguliere opleidingen op MBO/LLW-niveau. Het aantal gediplomeerden van deze opleidingen ligt in de Onderwijsrekeningen bijna 16.000 hoger dan bij de gegevens van de arbeidsmarktinstroomprognoses. Dit verschil komt overeen met een kwart van het totaal aantal gediplomeerden op dit opleidingsniveau uit de Onderwijsrekeningen.

Ook blijkt uit deze vergelijking dat zowel absoluut als relatief gezien de richtingveranderende niet-reguliere opleidingen in de Onderwijsrekeningen hoger liggen dan bij de huidige methodiek ter bepaling van de arbeidsmarktinstroom. Opvallend is eveneens dat in de Onderwijsrekeningen het aantal gediplomeerden van de niet-reguliere opleidingen op VBO-niveau lager is dan bij de arbeidsmarktinstroomprognoses in de huidige methodiek.

Hieruit zou geconcludeerd kunnen worden dat bij de huidige methodiek van de prognoses van de arbeidsmarktinstroom te weinig niveauverhogende of richtingveranderende nietreguliere opleidingen worden meegenomen. In de Onderwijsrekeningen liggen de stromen aanzienlijk hoger. Ook blijkt dat de veronderstelling dat voor personen ouder dan 30 jaar de niet-reguliere opleidingen hun kwalificatieprofiel niet verandert niet opgaat. Uit de Onderwijsrekeningen blijkt dat niet-reguliere opleidingen ook voor personen van ouder dan 30 jaar nog vaak niveauverhogend of richtingveranderend van aard zijn, waardoor er een verandering optreedt in hun kwalificatieprofiel. Als laatste kan geconcludeerd worden dat in 
de huidige methodiek van de arbeidsmarktinstroomprognoses de mate van de richtingveranderende niet-reguliere opleidingen wordt onderschat. Daarbij moet echter wel de kanttekening worden gemaakt dat de hier gepresenteerde analyses betrekking hebben op een verandering in de SOI-5-digit code van de opleidingsachtergrond. Een deel van deze veranderingen zal zich waarschijnlijk binnen hetzelfde opleidingstype afspelen. Een dergelijke vergelijking op het niveau van de verschillende opleidingstypen is hier niet gemaakt, omdat de laatste prognoses nog met de oude opleidingsindeling zijn gemaakt ${ }^{9}$.

In tabel 4.2 wordt een overzicht gegeven van de verschillen tussen de gegevens uit de Onderwijsrekeningen (tabel 3.10) en de laatste prognoses van de arbeidsmarktinstroom vanuit het niet-reguliere onderwijs (tabel 2.4) verbijzonderd naar opleidingsniveau, -richting en vooropleiding.

Het verschil tussen de Onderwijsrekeningen en de arbeidsmarktinstroomprognoses is absoluut gezien het grootst bij de economische, administratieve en commerciële opleidingen, waar het aantal gediplomeerden, waarbij er sprake is van een niveauverhogende of richtingveranderende opleiding, in de Onderwijsrekeningen ruim 25.000 hoger ligt dan bij de huidige prognosemethodiek. Daarna zijn de verschillen het grootst bij de technische en de persoonlijk verzorgende opleidingen. Bij beide richtingen ligt het aantal gediplomeerden in de Onderwijsrekeningen circa 9.000 hoger. Bij de algemene en sociaal-culturele opleidingsrichtingen bedraagt het verschil ongeveer 7.000 personen.

Verbijzonderd naar opleidingsniveau, blijkt dat bij de niet-reguliere opleidingen op HBOniveau en hoger de verschillen tussen de gegevens uit de Onderwijsrekeningen en de arbeidsmarktinstroom naast de economische richtingen, ook bij de (para)medische opleidingsrichtingen redelijk groot zijn. Op HBO-niveau neemt de Onderwijsrekeningen eveneens meer gediplomeerden van niveauverhogende of richtingveranderende kunstopleidingen waar.

Tabel 4.2

Verschillen in aantal niveauverhogende en richtingveranderende gediplomeerden uit het niet-regulier onderwijs naar onderwijsniveau en -richting (OR ten opzichte van huidige methodiek), 1994

\begin{tabular}{|c|c|c|c|c|c|}
\hline \multirow[t]{2}{*}{ Opleidingsrichting } & \multicolumn{5}{|c|}{ Opleidingsniveau } \\
\hline & 3 & 4 & 5 & $6 / 7$ & Totaal \\
\hline \multicolumn{6}{|l|}{ Aantallen } \\
\hline Algemeen/Lerarenopleidingen & -500 & 7.300 & -400 & 800 & 7.200 \\
\hline Humaniora/Theologie & -400 & - . & - . & 600 & 200 \\
\hline Agrarisch & -200 & 2.700 & 300 & 200 & 3.000 \\
\hline Techniek, wis- en natuurkunde & 900 & 7.700 & 200 & 700 & 9.500 \\
\hline
\end{tabular}

9. Met ingang van 1997 wordt de nieuwe ROA-opleidingsindeling gehanteerd (Heijke, Matheeuwsen en Willems, 1997. 
Transport, communicatie en verkeer

(Para)medisch

Economisch, administatief en commercieel

$\begin{array}{rrrrr}1.300 & 1.300 & 500 & - & 3.100 \\ . & -800 & 1.500 & 1.300 & 2.000 \\ 200 & 15.800 & 8.000 & 1.800 & 25.800 \\ 200 & 2.100 & 2.500 & 1.900 & 6.700 \\ 1.100 & 7.400 & 500 & - & 8.900 \\ . \cdot & 500 & 1.100 & 500 & 2.000 \\ 800 & -600 & -400 & - & -200 \\ -. & 700 & -. & - & 700\end{array}$

Sociaal-cultureel

Persoonlijke verzorging

Kunst

Openbare orde en veiligheid

Overig onderwijs

3.400

44.100

13.600

7.700

68.900

Relatief

Algemeen/Lerarenopleidingen

Humaniora/Theologie

Agrarisch

Techniek, wis- en natuurkunde

Transport, communicatie en verkeer

(Para)medisch

Economisch, administatief en commercieel

Sociaal-cultureel

Persoonlijke verzorging

Kunst

Openbare orde en veiligheid

Overig onderwijs

$\begin{array}{rrrrr}\% & \% & \% & \% & \% \\ -14 & 6 & -18 & 1 & 2 \\ -6 & -0 & -2 & -9 & -1 \\ -4 & 1 & 1 & 2 & 1 \\ -1 & -7 & -3 & 3 & -7 \\ 12 & 0 & 3 & - & 1 \\ 0 & -7 & -5 & 13 & -4 \\ -4 & 4 & 22 & 6 & 6 \\ 2 & 1 & 3 & -17 & 3 \\ 10 & 3 & 2 & - & 2 \\ -0 & 1 & 3 & 2 & 1 \\ 3 & -4 & -7 & - & -4 \\ -0 & 1 & -0 & - & 1\end{array}$

Bron: ROA

In vergelijking met de andere opleidingsniveau's ligt bij de niveauverhogende of richtingveranderende niet-reguliere opleidingen op VBO-niveau het aantal gediplomeerden in de Onderwijsrekeningen voor de opleidingsrichtingen met betrekking tot transport, communicatie en verkeer, persoonlijke verzorging en openbare orde en veiligheid hoger dan bij de huidige methodiek van de instroomprognoses. De kwalificatieveranderende niet-reguliere algemene en humaniora opleidingen op VBO-niveau blijken daarentegen volgens de Onderwijsrekeningen op een lager niveau te liggen dan bij de huidige aanpak van de arbeidsmarktinstroomprognoses.

In de Onderwijsrekeningen worden de meeste niveauverhogende of richtingveranderende niet-reguliere economische-opleidingen op MBO/LLW-niveau gevolgd op het gebied van de detailhandel, namelijk 5.300. Na de detailhandel zijn de niet-reguliere economische opleidingen op het gebied van bedrijfsadministratie het grootst met circa 5.000 personen, gevolgd door bedrijfskunde/management met 3.300 personen, overig administatief met 2.600 personen en secretarieel met 2.400 personen.

De niveauverhogende en richtingveranderende niet-reguliere algemene opleidingen op VBO-niveau zijn allen (deeltijd) MAVO-opleidingen. Op MBO/LLW-niveau zijn dit voornamelijk HAVO/VWO, leraren lichamelijke opvoeding en leraren persoonlijke/sociale verzorging.

Als de opleidingen in het leerlingwezen apart worden bekeken, blijkt dat bij de huidige aanpak van de arbeidsmarktinstroomprognoses relatief gezien bij een te groot deel van de 
instroom als vooropleiding basisonderwijs wordt verondersteld, terwijl het aandeel van de vooropleidingen $\mathrm{MBO} / \mathrm{LLW}$ verzorging en HAVO/VWO wordt onderschat. Bij de huidige methodiek worden relatief gezien meer opleidingen motorvoertuigentechniek, elektrotechniek en MAVO (persoonlijke en maatschappelijke vorming) afgerond dan in de Onderwijsrekeningen. Daarentegen worden er bij de huidige aanpak relatief minder leerlingwezenopleidingen met succes afgerond op het gebied van handel, verzorging en grafische techniek.

Tabel 4.3 geeft per opleidingsniveau een overzicht van het netto-effect van de niveauverhogende of richtingveranderende niet-reguliere opleidingen op basis van enerzijds de Onderwijsrekeningen en anderzijds de huidige methodiek van de arbeidsmarktinstroomprognoses. Uit de tabel blijkt dat ook het netto-effect van de niveauverhogende of richtingveranderende niet-reguliere opleidingen op basis van de Onderwijsrekeningen in het algemeen op een hoger niveau ligt dan de arbeidsmarktinstroom van schoolverlaters zoals die bij de laatste prognoses is bepaald. Op jaarbasis is het verschil in aantal gediplomeerden van het niveauverhogende of richtingveranderende niet-reguliere onderwijs het grootst op MBO/LLW-niveau. Volgens de Onderwijsrekeningen is in 1994 het aantal gediplomeerden van niveauverhogende of richtingveranderende niet-reguliere $\mathrm{MBO} / \mathrm{LLW}$-opleidingen 45.000 , terwijl deze stroom volgens de huidige methodiek slechts 21.400 is, ongeveer de helft. Ook op (Post-)WO-niveau ligt volgens de huidige methodiek de arbeidsmarktinstroom van niet-reguliere opleidingen veel lager dan bij de Onderwijsrekeningen. Het netto-effect van het niveauverhogende of richtingveranderende onderwijs op basisonderwijs-niveau wordt daarentegen door de huidige methodiek overschat. Volgens de Onderwijsrekeningen ligt de doorstroom vanuit het basisonderwijs naar een niveauverhogende of richtingveranderende niet-reguliere opleiding 1.700 hoger dan in de huidige methodiek.

Tabel 4.3

Netto-effect van het niveauverhogende of richtingveranderende niet-reguliere onderwijs naar onderwijsniveau, 1994

\begin{tabular}{lrrr}
\hline Opleidingsniveau & $\begin{array}{c}\text { Onderwijs- } \\
\text { rekeningen }\end{array}$ & $\begin{array}{c}\text { Huidige } \\
\text { Methodiek }\end{array}$ & Verschil \\
\hline B Basisonderwijs & 13.000 & 14.900 & -1.700 \\
3 VBO, MAVO & 45.000 & 21.400 & 23.500 \\
4 MBO/LLW, HAVO/VWO & 41.000 & 30.700 & 10.600 \\
5 HBO & 9.000 & 5.000 & 3.800 \\
6 WO (incl. 7 Post-WO) & 8.000 & 1.700 & 6.200 \\
\hline
\end{tabular}

Bron: $\mathrm{CBS} / \mathrm{ROA}$

In tabel 4.4 wordt de onderschatting van de gediplomeerden van de niveauverhogende of richtingveranderende niet-reguliere opleidingen op basis van de huidige aanpak van de arbeidsmarktinstroomprognoses en de Onderwijsrekeningen afgezet tegen het aantal werkenden verbijzonderd naar opleidingsniveau. Ook de relatieve onderschatting van de arbeidsmarktinstroom van schoolverlaters uit het niet-reguliere onderwijs blijkt het grootst te zijn op MBO/LLW-niveau en (Post-)WO-niveau, met respectievelijk 1,8 en 1,3\%. 
Tabel 4.4

Absolute en relatieve onderschatting van het aantal gediplomeerden uit het niveauverhogende of richtingveranderende onderwijs op basis van de huidige methodiek, 1994

\begin{tabular}{lrrr}
\hline Opleidingsniveau & $\begin{array}{r}\text { Absolute onder- } \\
\text { schatting }\end{array}$ & $\begin{array}{r}\text { Aantal werkenden } \\
\text { gemiddelde 1994/'95 }\end{array}$ & $\begin{array}{r}\text { Relatieve onder- } \\
\text { schatting }\end{array}$ \\
\hline 2 Basisonderwijs & -1.700 & 495.500 & 0,3 \\
3 VBO, MAVO & 23.500 & 1.330 .500 & 1,8 \\
4 MBO/LLW, HAVO/VWO & 10.600 & 2.643 .500 & 0,4 \\
5 HBO & 5.000 & 1.027 .500 & 0,5 \\
6 WO (incl. 7 Post-WO) & 6.200 & 463.000 & 1,3 \\
\hline
\end{tabular}

Bron: $\mathrm{CBS} / \mathrm{ROA}$

Bij de huidige methodiek van de arbeidsmarktinstroomprognoses wordt de prognose van het reguliere voltijdonderwijs (stap 1) bijgesteld op basis van de prognose van het nietreguliere onderwijs. Tabel 4.5 geeft de uiteindelijke arbeidsmarktinstroom van schoolverlaters in 1994, waarbij de prognose van het reguliere voltijdonderwijs (op basis van de huidige methodiek) is bijgesteld op basis van het niet-reguliere onderwijs volgens de Onderwijsrekeningen en de huidige methodiek. Op de meeste opleidingsniveau's wordt de uiteindelijke instroom van schoolverlaters naar de arbeidsmarkt volgens de huidige aanpak onderschat. Op MBO/LLW-niveau bijvoorbeeld is op basis van de cijfers die kunnen worden afgeleid uit de Onderwijsrekeningen de instroom van schoolverlaters naar de arbeidmarkt 123.800 , terwijl deze bij de huidige methodiek circa 10.000 personen lager ligt op 113.200. Alleen de arbeidsmarktinstroom van schoolverlaters met VBO-niveau wordt aanzienlijk overschat in de huidige methodiek en zal zelfs op basis van de gegevens uit de Onderwijsrekeningen negatief worden.

Tabel 4.5

Arbeidsmarktinstroom van schoolverlaters: regulier voltijdonderwijs (huidige methodiek) bijgesteld op basis van het niet-reguliere onderwijs volgens de Onderwijsrekeningen en de huidige methodiek, 1994

\begin{tabular}{lrr}
\hline Opleidingsniveau & $\begin{array}{c}\text { Onderwijs- } \\
\text { rekeningen }\end{array}$ & $\begin{array}{r}\text { Huidige } \\
\text { Methodiek }\end{array}$ \\
\hline 2 Basisonderwijs & 10.200 & \\
3 VBO, MAVO & -3.100 & 20.400 \\
4 MBO/LLW, HAVO/VWO & 123.800 & 113.200 \\
S HBO & 42.700 & 37.700 \\
W WO (incl. 7 Post-WO) & 32.600 & 26.400
\end{tabular}

Bron: ROA

\section{Samenvatting en conclusie}


In dit werkdocument is onderzocht in hoeverre de Onderwijsrekeningen mogelijkheden bieden om de kwaliteit van de prognoses van de arbeidsmarktinstroom vanuit het nietreguliere onderwijs te verbeteren. Om hier een beeld van te krijgen, zijn de huidige prognoses voor het niet-reguliere onderwijs vergeleken met de aan de EBB ontleende gegevens over het niet-reguliere onderwijs uit de Onderwijsrekeningen.

Op basis van deze vergelijkingen kunnen de volgende conclusies worden getrokken:

- Bij de huidige methodiek van de prognoses van de arbeidsmarktinstroom worden te weinig niveauverhogende danwel richtingveranderende niet-reguliere opleidingen meegenomen. Daarbij moet echter wel de kanttekening worden gemaakt dat de hier gepresenteerde analyses betrekking hebben op een verandering in de SOI-5-digit code van de opleidingsachtergrond. Een deel van deze veranderingen zal zich waarschijnlijk binnen hetzelfde opleidingstype afspelen.

- Verbijzonderd naar opleidingsniveau is deze onderschatting absoluut gezien het grootst bij de niet-reguliere opleidingen op MBO/LLW-niveau.

- In de huidige methodiek van de arbeidsmarktprognoses wordt de omvang van de richtingveranderende niet-reguliere opleidingen onderschat.

- Verbijzonderd naar de opleidingsrichting blijkt de onderschatting het grootst bij de economische en sociaal-culturele opleidingen binnen het niet-reguliere onderwijs. Op MBO/LLW-niveau wordt in de huidige methodiek ook de doorstroom naar de technische, persoonlijk verzorgende en algemene niet-reguliere opleidingsrichtingen onderschat.

- De veronderstelling dat voor personen ouder dan 30 jaar de gevolgde niet-reguliere opleidingen het kwalificatieprofiel niet verandert, blijkt niet op te gaan. Ook voor personen van 30 jaar en ouder blijkt dat de niet-reguliere opleidingen voor een deel niveauverhogend of richtingveranderend van aard zijn ${ }^{10}$.

- Het aantal niet-reguliere openbare orde en veiligheidsopleidingen op HBO- en WOniveau is te klein om op basis van de Onderwijsrekeningen gepresenteerd te kunnen worden.

In het algemeen bieden de Onderwijsrekeningen goede mogelijkheden om de kwaliteit van de prognoses van de arbeidsmarktinstroom vanuit het niet-reguliere onderwijs te verbeteren. Door het gebruik van de gegevens met betrekking tot het niet-reguliere onderwijs uit de Onderwijsrekeningen wordt ook de consistentie met de vraagprognoses verbeterd, omdat aan deze vraagprognoses eveneens de EBB ten grondslag ligt.

Voor de bepaling van de prognoses van de arbeidsmarktinstroom vanuit het niet-reguliere onderwijs zou het de voorkeur verdienen als er op basis van de verschillende Onderwijsrekeningen een tijdreeks zou kunnen worden samengesteld van het aantal gediplomeerden, verbijzonderd naar vooropleiding. Op basis van de momenteel beschikbare Onderwijsreke-

10. Wanneer bij de arbeidsmarktprognoses met deze kwalificatieverandering van het arbeidsaanbod rekening wordt gehouden, zal wel afstemming moeten plaatsvinden met de vervangingsvraagprognoses naar opleidingstype, die immers beïnvloed worden door de veranderingen in de opleidingsachtergrond van de werkenden bij de oudere leeftijdsgroepen. 
ningen zou reeds een tijdreeks van de niveauverhogende en richtingveranderende nietreguliere opleidingen voor de jaren 1989-1994 kunnen worden samengesteld. Het afbakenen van het leerlingwezen geeft echter problemen bij de Onderwijsrekeningen in de jaren vóór 1995/'96 omdat in deze jaren het identificatienummer van de opleiding nog niet is opgenomen.

Wel zal bij de bepaling van de arbeidsmarktinstroomprognoses gebruik blijven worden gemaakt van de prognoses die het Ministerie van Onderwijs, Cultuur en Onderwijs geeft voor enkele niet-reguliere opleidingen in de Referentieraming. Het betreft hier de prognoses van de schoolverlaters van het deeltijdonderwijs HAVO/VWO, MAVO en enkele deeltijdopleidingen op MBO- en HBO-niveau en de prognoses van de schoolverlaters van het primaire, secundaire en tertiare leerlingwezen. Deze prognoses zullen met de meer gedetailleerde gegevens over deze opleidingen uit de Onderwijsrekeningen worden verbijzonderd naar opleidingstype, terwijl bovendien gebruik kan worden gemaakt van de informatie over de vooropleiding van de gediplomeerden van deze niet-reguliere opleidingen. Hierbij zal, in de Onderwijsrekeningen gebruik worden gemaakt van het identificatienummer van de gevolgde opleidingen.

\section{Literatuur}

Borghans L. en A. Matheeuwsen (1997), Forecasting educational outflow per type of education, ROA, Maastricht (verschijnt binnenkort).

Centraal Bureau voor de Statistiek (1992), Kwartaalschrijft Onderwijs-Statistieken 1995-I en II, Voorburg/Heerlen.

Centraal Bureau voor de Statistiek (1996), Onderwijsrekeningen 1995/'96, Voorburg/Heerlen.

Grip, A. de, M. van Smoorenburg, L. Borghans, N. Jonker (1997), Werkgelegenheid en scholing 1996, ROA-R-1997/1, Maastricht.

Heijke, H., A. Matheeuwsen, E. Willems (1997), Clustering educational categories in a heterogeneous labour market, ROA, Maastricht (verschijnt binnenkort).

Ministerie van Onderwijs, Cultuur en Wetenschappen (1995), Referentieraming 1995, Zoetermeer.

ROA (1995), De arbeidsmarkt naar opleiding en beroep tot 2000, ROA-R-1995/3, Maastricht.

ROA (1996), Statistische Bijlage De arbeidsmarkt naar opleiding en beroep tot 2000, Actualisering 1996, ROA-R-1996/8B, Maastricht. 